
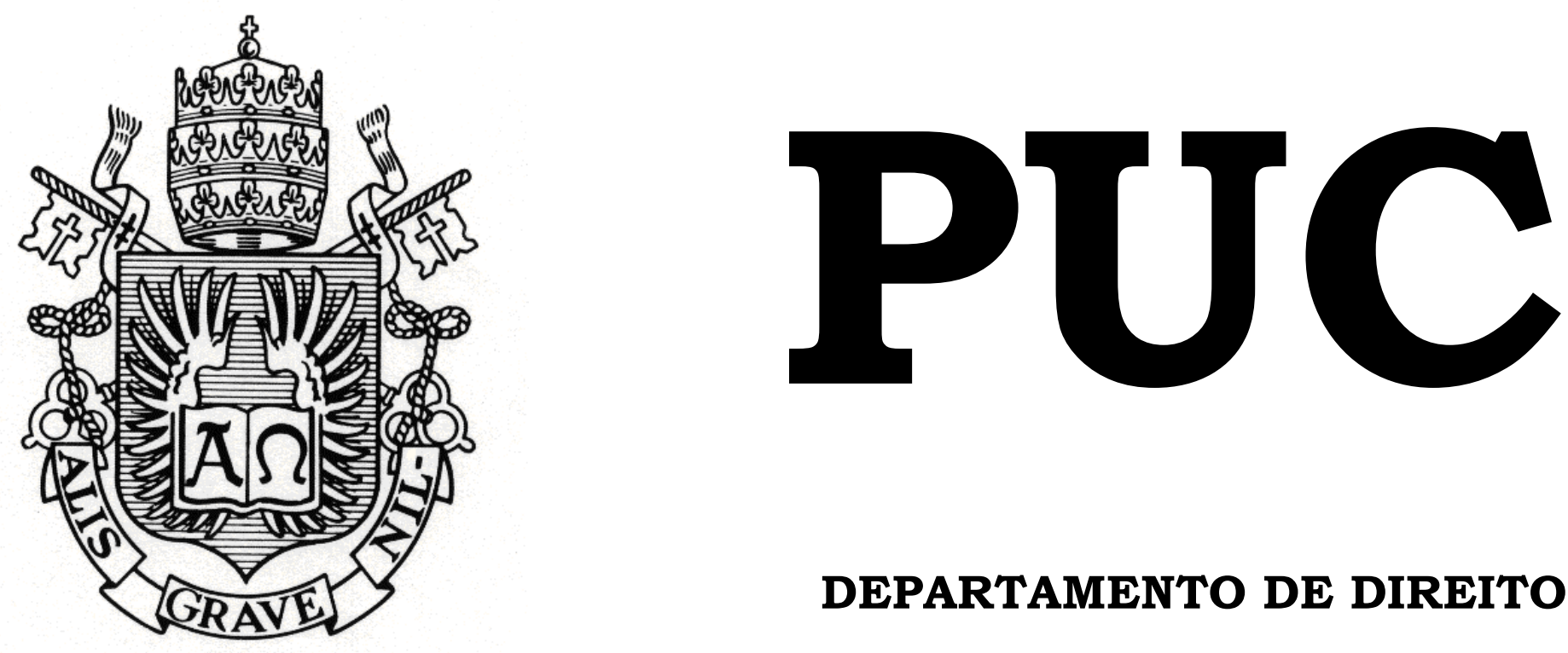

DEPARTAMENTO DE DIREITO

\title{
AUTOS DE RESISTÊNCIA: O EXTERMÍNIO DOS INVISÍVEIS
}

por

GABRIELA FENSKE FELDKIRCHER

ORIENTADOR(A): João Ricardo Dornelles

COORIENTADOR(A): Victoria-Amália de B. C. G. Sulocki

\section{1}

PONTIFÍCIA UNIVERSIDADE CATÓLICA DO RIO DE JANEIRO

RUA MARQUÊS DE SÃO VICENTE, 225 - CEP 22453-900

RIO DE JANEIRO - BRASIL 


\title{
AUTOS DE RESISTÊNCIA: O EXTERMÍNIO DOS INVISÍVEIS
}

\author{
por \\ GABRIELA FENSKE FELDKIRCHER
}

Monografia

apresentada ao

Departamento de Direito da Pontificia Universidade Católica do Rio de Janeiro (PUC-Rio) para a obtenção do Título de Bacharel em Direito.

Orientador(a): João Ricardo Dornelles

Coorientador(a): Victoria-Amália de B.

C. G. Sulocki 
Às vítimas invisíveis da política de extermínio do Estado brasileiro.

Aos seus familiares e amigos(as) que resistem e lutam diariamente pela memória digna do ente/amigo(a) perdido(a).

À luta que, apesar de dura, é necessária.

A um futuro onde não existam invisíveis, nem para o Estado, nem para a sociedade.

A um futuro onde palavras como justiça e igualdade sejam mais do que palavras de ocasião. 


\section{Agradecimentos}

À minha mãe, Elfi Fenske, pelas escolhas que fez em sua vida que fizeram dela a mulher extraordinária que é e, refletiram para que eu seja como sou. À minha madrinha, Eli Fenske, pelo amor incondicional e, por ter sido minha segunda mãe, literalmente, em um dos períodos mais importantes da minha vida.

Aos meus avós, Erna Fenske e Afonso Fenske, por serem o meu porto seguro e por me ensinarem que a beleza da vida encontra-se nos pequenos momentos, nos gestos mais singelos.

Aos demais integrantes da minha família por estarem sempre por perto, por me apoiarem e me amarem incondicionalmente.

Ao Adair Rocha pela oportunidade concedida, um presente que me fez crescer pessoal e profissionalmente.

Aos meus amigos, em especial Clarice Lippmann, Juliana Ludmer e Fabrício Cavallari, por compartilharem comigo histórias, sorrisos, choros, abraços, muitas cervejas e/ou ice teas e muitas conversas de bar. Enfim, pela amizade mais do que sincera.

À eterna Contra Corrente por ter me proporcionado os melhores anos da faculdade, muitos aprendizados e grandes amigos.

Ao Rafael Scotti pelos sorrisos arrancados no último semestre, por ter dado um pouco de serenidade ao caos que se instalou na minha vida.

À Anna Carolina Pinto e ao Luiz Rodolfo Viveiros de Castro por terem acompanhado de perto a saga da monografia e o meu "chorar de pitangas" quase que diário. Pela paciência, incentivo, carinho e, acima de tudo, pela amizade.

Ao Marcelo Chalréo, pela amizade, ensinamentos e experiências compartilhadas. Pela figura inspiradora na luta pelos direitos dos mais necessitados.

Aos amigos da Comissão de Direitos Humanos da OAB/RJ pela luta diária em prol dos invisíveis da sociedade. 
À Victoria Sulocki, ao João Ricardo Dornelles e aos demais professores, da PUC e da vida, pelos ensinamentos compartilhados dentro e fora da sala de aula.

E, por fim, a todos aqueles que passaram em algum momento pela minha vida e acrescentaram de algum modo. 


\section{Resumo}

O presente trabalho objetiva a análise dos autos de resistência, à luz da construção histórica brasileira, doutrina, legislação pertinente, e breve estudo de casos, visando melhor compreensão do referido instituto, bem como as consequências de seu uso, eis que largamente utilizado para justificar mortes de indivíduos socialmente vulneráveis em assassinatos cometidos pela polícia. A importância do estudo evidencia-se não só pela frequência com que os autos são utilizados mas, principalmente, por corroborarem com as noções de estado de exceção e a condição de homo sacer presentes no pensamento de Agamben e, também, pelo papel exercido pelo instituto em questão na fracassada política de segurança pública fluminense, marcada por recorrentes episódios de violações de direitos humanos.

Palavras-chave: estado de exceção; violência policial; autos de resistência; processo penal; segurança pública; homo sacer 


\section{Autos de Resistência: o extermínio dos invisíveis}

\section{Sumário}

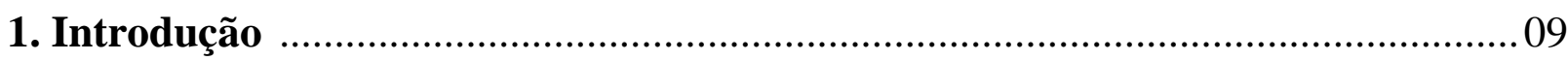

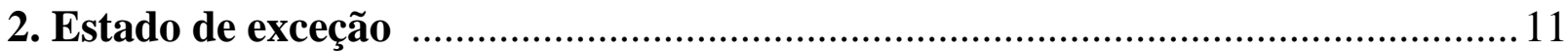

2.1. A formação do Estado brasileiro e o estado de exceção....................................... 14

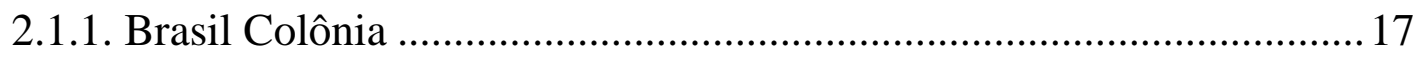

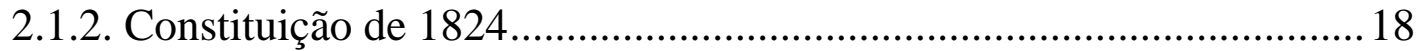

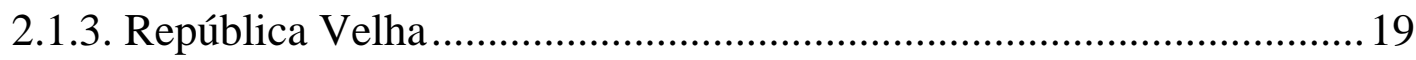

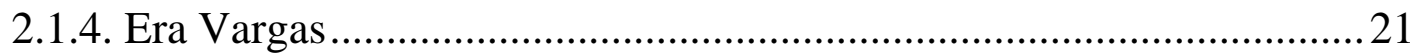

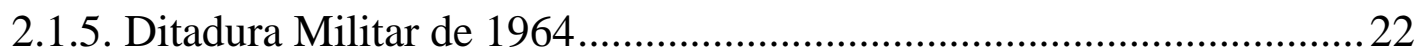

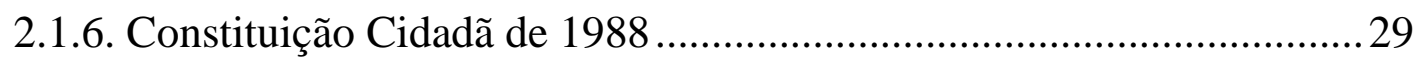

3. Autos de Resistência: o extermínio dos invisíveis ...................................................... 37

3.1. Quando o procedimento vira processo ……………………….......................... 43

3.1.1. Registro de Ocorrência............................................................................ 43

3.1.2. Inquérito Policial................................................................................. 48

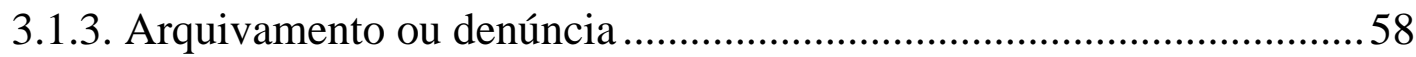

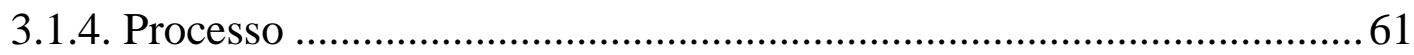

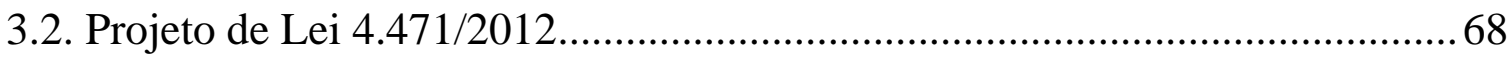

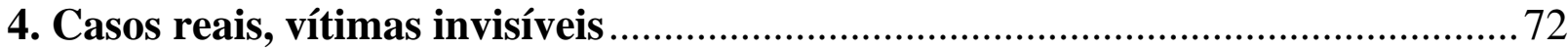

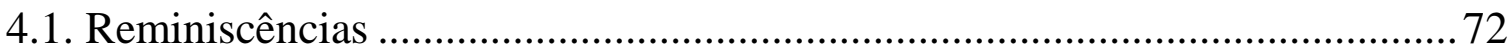

4.2. Inimigos de uma guerra particular, a banalização da morte …………………... 77

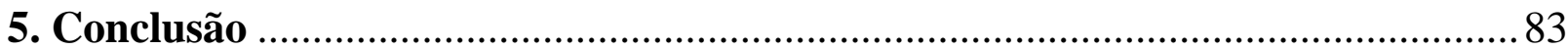

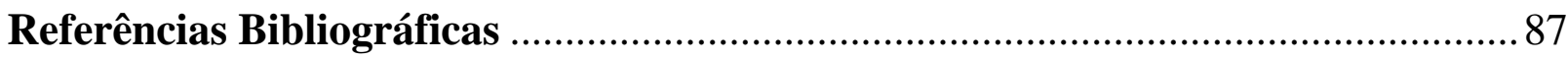




\section{Lista de abreviações}

AI - Ato Institucional

AIJ - Audiência de Instrução e Julgamento

AISP - Área Integrada de Segurança Pública

CDDPH - Conselho de Defesa dos Direitos da Pessoa Humana

CIDH - Corte Interamericana de Direitos Humanos

CIE - Centro de Informações do Exército

CNDH - Conselho Nacional dos Direitos Humanos

CNV - Comissão Nacional da Verdade

CPP - Código de Processo Penal

DOI-CODI - Destacamento de Operações de Informação - Centro de

Operações de Defesa Interna

DP - Delegacia de Polícia

EC - Emenda Constitucional

FAC - Folha de Antecedentes Criminais

IBGE - Instituto Brasileiro de Geografia e Estatística

ICCE - Instituto de Criminalística Carlos Éboli

IML - Instituto Médico Legal

MP - Ministério Público

OAB - Ordem dos Advogados do Brasil

OEA - Organização dos Estados Americanos

PIP - Promotoria de Investigação Penal

PM - Polícia Militar

PNAD - Pesquisa Nacional por Amostra de Domicílio

RO - Registro de Ocorrência

SESEG - Secretaria de Estado de Segurança

SFICI - Serviço Federal de Informações e Contra-Informações

SNI - Serviço Nacional de Informações

UPP - Unidade de Polícia Pacificadora 
"Os ninguéns: os filhos de ninguém, os donos de nada.

Os ninguéns: os nenhuns, correndo soltos, morrendo a vida, fodidos e mal pagos:

Que não são, embora sejam.

Que não falam idiomas, falam dialetos.

Que não praticam religiões, praticam superstições.

Que não fazem arte, fazem artesanato.

Que não são seres humanos, são recursos humanos.

Que não tem cultura, têm folclore.

Que não têm cara, têm braços.

Que não têm nome, têm número.

Que não aparecem na história universal, aparecem nas páginas policiais da imprensa local.

Os ninguéns, que custam menos do que a bala que os mata."

(Eduardo Galeano ${ }^{1}$ )

\footnotetext{
${ }^{1}$ GALEANO, Eduardo. O livro dos abraços. Porto Alegre: L\&PM, 2002.
} 


\section{Introdução}

O estado do Rio de Janeiro tem o maior índice de homicídios praticados por policiais se comparado com as polícias de países civilizados. Entre 2001 e 2011 foram mais de dez mil mortes ${ }^{2}$ e, apenas este ano (2015), entre janeiro e abril, foram 260 mortes $^{3}$ registradas como "autos de resistência".

Direcionada a classes e grupos sociais excluídos com o intuito de garantir o controle social e a segurança de outra parcela da população, a atual política de segurança pública vai ceifando vidas, acabando com sonhos e construindo uma sociedade baseada no ódio e na vingança.

Diante desse quadro, o presente estudo tem por objetivo expor a origem dessa prática, indicá-la como uma das principais ferramentas de manutenção do estado de exceção a um segmento específico da população que vive na condição de homo sacer, bem como, demonstrar que o estado de exceção sempre esteve presente na história do Brasil. E, por fim, tem por objetivo suscitar o debate sobre o que leva essa prática a perdurar e a manter seus responsáveis impunes.

O trabalho de conclusão de curso foi distribuído em três capítulos, permeados por abordagens críticas à política de segurança pública.

O capítulo 2 inicia-se apresentando brevemente o conceito de estado de exceção dos autores Carl Schmitt, Giorgio Agamben e Walter Benjamin. Posteriormente, apresenta um delineamento histórico da formação do Estado brasileiro, apontando que em todos os momentos da história houve e há classes e grupos sociais excluídos, invisíveis para a sociedade e que viveram e vivem na condição de homo sacer e, portanto, em um estado de exceção, este ajustado à realidade brasileira, conforme as categorias propostas por José Ribas Vieira. A trajetória apresentada inicia-se nos tempos do Brasil colonial e se encerra na Constituição de 1988.

\footnotetext{
${ }^{2}$ MISSE, Michel; GRILLO, Carolina Christoph; TEIXEIRA, César Pinheiro; NERI, Natasha Elbas. Quando a polícia mata: homicídios por "autos de resistência" no Rio de Janeiro (20012011). Rio de Janeiro: NECVU; Booklink, 2013, p. 11.

${ }^{3}<$ http://www.isp.rj.gov.br/>. Acesso em: 04.06.2015.
} 
No capítulo 3, é realizada a contextualização da criação dos "autos de resistência", sua previsão legal advinda dos anos de chumbo. Em seguida, para que seja compreendido melhor esse instituto e como é o seu funcionamento na prática, são apresentadas todas as etapas do procedimento, que principia no Registro de Ocorrência e encerra-se no Processo Judicial. Ademais, nesse percurso, são também analisados e expostos os discursos e comportamentos de todos os atores judiciários (policiais, delegados, promotores, juízes) que são fundamentais para a elucidação dos casos. Por fim, aborda-se brevemente o Projeto de Lei $4.471 / 2012$.

O capítulo 4 tem por objetivo ilustrar os "autos de resistência", apresentando uma série de casos, bem como, demonstrar que sua ocorrência remonta ao Brasil colonial, sendo, portanto, anterior a sua previsão legal. Posteriormente, é abordada a política de segurança pública do estado do Rio de Janeiro a partir dos anos 1990, com citações a uma série de ocorrências e casos que resultaram em mortes de civis, a maior parte delas ainda impunes e sequer investigadas.

Nas considerações finais, são apresentadas as conclusões parciais da pesquisa, sem pretensões de apresentar soluções, mas com o ensejo de que o debate seja aberto e que a sociedade reflita acerca do tema, considerando os impactos que o uso indiscriminado do instituto representa na vida de inúmeras pessoas. 


\section{Estado de exceção}

O conceito "estado de exceção" tem origem na doutrina alemã (Ausnahmezusand), e seu estudo como teoria foi inaugurado por Carl Schmitt no ensaio intitulado Die Diktatur (A ditadura), publicado em 1921.

Importante pontuar, para que seja dado ao leitor maior entendimento acerca das circunstâncias em que o conceito foi originado, que em 1921 encontrava-se em vigor na Alemanha a Constituição de Weimar (19191933), fruto do fim da Primeira Guerra Mundial.

Ademais, frisa-se que a sociedade alemã, na época, encontrava-se fragmentada em grupos de interesses contrapostos, o que refletia no enfraquecimento do Estado e atingia diretamente a ordem constitucional. Fatores esses que, posteriormente, em conjunto com uma interpretação do art. $48^{4}$ da referida Carta, deram ensejo à instalação do Estado Totalitário que dotou o partido nazista de poder mais amplo do que o poder Estatal ${ }^{5}$, todo ele concentrado na figura do ditador. Vale ressaltar ainda que, tecnicamente, a Constituição de Weimar continuou a vigorar durante toda a existência do Terceiro Reich (1933-1945), apesar de terem sido suspensos os artigos relativos às liberdades individuais pelo Decreto para a proteção do povo e do Estado promulgado em 28 de fevereiro de 1933 por Hitler.

Isto posto, vale dizer que, para Schmitt, o conceito de estado de exceção vem da ideia de que um governo deve incluir na sua Constituição um elemento ditatorial, de modo a livrar o Executivo de qualquer restrição legal ao seu poder. O estado de exceção é, portanto, um "privilégio" do soberano, ou seja, cabe a ele instaurá-lo. O "soberano é quem decide sobre o estado de exceção",

\footnotetext{
${ }^{4}$ Art. 48 da Constituição de Weimar: "Se, no Reich alemão, a segurança e a ordem pública estiveram seriamente (erheblich) conturbadas ou ameaçadas, o presidente do Reich pode tomar as medidas necessárias para o restabelecimento da segurança e da ordem pública, eventualmente com a ajuda das forças armadas. Para esse fim, ele pode suspender total ou parcialmente os direitos fundamentais (Grundrechte), estabelecidos nos artigos 114, 115, 117, 118, 123, 124 e 153.”.

${ }_{5}$ AUAD, Denise. Os direitos sociais na Constituição de Weimar como paradigma do modelo de proteção social da atual Constituição Federal Brasileira. In Revista da Faculdade de Direito da Universidade de São Paulo, jan/dez. 2008, v. 103, 340 p. - Disponível em: <http://www.revistas.usp.br/rfdusp/article/viewFile/67809/70417>. Acesso em 11.05.2015.

${ }^{6}$ SCHMITT, Carl. Teologia política. Belo Horizonte: Del Rey, 2006, p. 7.
} 
Segundo Taiguara ${ }^{7}$, para Schmitt, o Estado tem como finalidade a pacificação completa do seu território, e para alcançar tal pressuposto, faz uso do estado de exceção, que existe para criar a situação na qual o direito poderá valer plenamente. Ou seja, o estado de exceção se justifica pela necessidade de manter a Constituição, que é a garantidora da paz social.

Logo, o Estado tem competência, através da soberania, de determinar quem é o inimigo e como combatê-lo. Sendo assim, o soberano tem plenos poderes para dispor da vida das pessoas, bem como, para declarar guerras. Aqui é possível vislumbrar a condição de homo sacer, trabalhado por Agamben ${ }^{8}$, figura jurídica do direito romano arcaico que é excluída de todos seus direitos civis e que é considerada matável, sem que recaia qualquer punibilidade sobre o autor do homicídio.

Agamben, em uma das suas principais obras, também estuda o estado de exceção e, por ser um autor contemporâneo, suas ideias são mais atuais. Seu enfoque, portanto, é mais pertinente no presente trabalho em detrimento do ideário de Schmitt.

Para Agamben, há uma dificuldade na definição do conceito, devido à estreita ligação do estado de exceção com a guerra civil, a insurreição e a resistência ${ }^{9}$, tendo em vista que essas situações são contrárias ao estado normal e que é "natural" que o Estado, em casos extremos, como os apontados, tenha como resposta imediata a implementação do estado de exceção a fim de resolver tais conflitos internos e reestabelecer a paz e a ordem.

No entanto, para o autor, é possível existir o estado de exceção nos Estados contemporâneos chamados democráticos. Em uma passagem de

\footnotetext{
${ }^{7}$ SOUZA, Taiguara Libano Soares. Constituição, Segurança Pública e Estado de Exceção Permanente: A Biopolítica dos Autos de Resistência. 2010. 217 p. Dissertação de Mestrado Departamento de Direitoda Pontifícia Universidade Católica do Rio de Janeiro, Rio de Janeiro, p. 29.

${ }^{8}$ AGAMBEN, Giorgio. Homo Sacer: o poder soberano e a vida nua. Belo Horizonte: Editora UFMG, 2002.

${ }^{9}$ AGAMBEN, Giorgio. Estado de exceção. São Paulo: Boitempo, 2004, p. 12.
} 
Estado de exceção, obra iniciada com citação ao totalitarismo, é possível perceber esse pensamento:

O totalitarismo moderno pode ser definido, nesse sentido, como a instauração, por meio do estado de exceção, de uma guerra civil legal que permite a eliminação física não só dos adversários políticos, mas também de categorias inteiras de cidadãos que, por qualquer razão, pareçam não intragáveis ao sistema político. Desde então, a criação voluntária de um estado de emergência permanente (ainda que, eventualmente, não declarado no sentido técnico) tornou-se uma das práticas essenciais dos Estados Contemporâneos, inclusive dos chamados democráticos ${ }^{10}$.

Logo, o estado de exceção não é algo que está fora da ordem jurídica, está dentro e fora, incluindo e excluindo, como bem pontua Taiguara $^{11}$.

Há que se considerar, portanto, que para o estado de exceção existir, é necessário, apenas, a vontade daquele ou daqueles que detêm o poder. As demais pessoas - diga-se de passagem, a maioria - estão à mercê dos interesses de uma pequena parcela da população que poderá dispor dos seus direitos mais básicos e fundamentais, como a vida, por exemplo.

Walter Benjamin, filósofo alemão, escreveu um importante texto a respeito do estado de exceção e que contribui bastante para o debate aqui proposto. Segundo ele,

A tradição dos oprimidos nos ensina que o "estado de exceção" em que vivemos é na verdade a regra geral. Precisamos construir um conceito de história que corresponda a essa verdade. Nesse momento, perceberemos que nossa tarefa é originar um verdadeiro estado de exceção; com isso, nossa posição ficará mais forte na luta contra o fascismo $^{12}$.

A ideia do opressor e do oprimido, figuras muito conhecidas ao longo da história, são muito marcantes nessa passagem. Benjamin consegue exprimir, em poucas palavras, que a sociedade vive um estado de exceção

\footnotetext{
${ }^{10}$ Ibid, p. 13.

${ }^{11}$ SOUZA, Taiguara Libano Soares. Constituição, Segurança Pública e Estado de Exceção Permanente: A Biopolítica dos Autos de Resistência. 2010. 217 p. Dissertação de Mestrado Departamento de Direitoda Pontifícia Universidade Católica do Rio de Janeiro, Rio de Janeiro, p. 31.

${ }^{12}$ BENJAMIIN, Walter. Magia e técnica, arte e política - Obras Escolhidas. Vol. 1. São Paulo: Brasiliense, 1987, p. 226.
} 
constante, que pode não ser notado por todos, mas que uma parcela específica da população vivencia diariamente por meio do emprego sistemático de violência pelo Estado, ou pela exclusão política e social a qual são submetidos.

\subsection{A formação do Estado brasileiro e o estado de exceção}

“... o Brasil sempre foi, ainda é, um moinho de gastar gentes. Construímo-nos queimando milhões de índios. Depois, queimamos milhões de negros. Atualmente, estamos queimando, desgastando milhões de mestiços brasileiros, na produção não do que eles consomem, mas do que dá lucro às classes empresariais."

(Darcy Ribeiro - O Brasil como problema)

Na história dos países latino-americanos ${ }^{13}$, o estado de exceção pode ser visualizado de modo extremamente claro, já que foram países colonizados e, portanto, tiveram seu território e seu povo explorados de maneira violenta desde o princípio. Ou seja, na América Latina o estado de exceção é permanente, tendo em vista que nos dias de hoje violações aos direitos humanos continuam sendo perpetradas pelos Estados e naturalizadas pela sociedade, que se cala.

No Estado brasileiro o estado de exceção pode ser sistematizado conforme propõem José Ribas Vieira ${ }^{14}$, que o divide em três categorias distintas:

a) Padrão clássico - ditadura constitucional (v. g. Alemanha Nazista);

b) Estado de exceção híbrido ou regime misto (v. g. Constituição de 1946);

c) Estado de exceção propriamente dito (Estado Novo e ditadura militar).

\footnotetext{
${ }^{13} \mathrm{O}$ autor Eduardo Galeano em seu livro "As veias abertas da América Latina” faz uma análise a respeito da história da América Latina do período da colonização europeia até os dias "atuais", mais especificamente até o ano de 1971, ano em que lançou o seu livro - GALENO, Eduardo. As veias abertas da América Latina. Rio de Janeiro: Paz e Terra, 1996.

${ }^{14}$ VIEIRA, José Ribas. O autoritarismo e a Ordem Constitucional no Brasil. Rio de Janeiro: Renovar, 1988, p. 46.
} 
A partir disso Taiguara em sua dissertação de mestrado, propôs o seguinte quadro cronológico ${ }^{15}$ do estado de exceção na história brasileira.

15 SOUZA, Taiguara Libano Soares. Constituição, Segurança Pública e Estado de Exceção Permanente: A Biopolítica dos Autos de Resistência. 2010. 217 p. Dissertação de Mestrado Departamento de Direitoda Pontifícia Universidade Católica do Rio de Janeiro, Rio de Janeiro, p. 117 


\begin{tabular}{|c|c|c|c|c|c|}
\hline $\begin{array}{c}\text { Período } \\
\text { histórico }\end{array}$ & Constituição & $\begin{array}{c}\text { Característica do } \\
\text { Estado de } \\
\text { exceção }\end{array}$ & $\begin{array}{c}\text { Decretos de } \\
\text { plenos } \\
\text { poderes }\end{array}$ & Aparato repressivo & $\begin{array}{l}\text { Inimigos } \\
\text { públicos }\end{array}$ \\
\hline Colônia & $\begin{array}{l}\text { Ordenações da } \\
\text { Coroa }\end{array}$ & $\begin{array}{l}\text { Excepcionalismo } \\
\text { colonial }\end{array}$ & $\begin{array}{l}\text { Inexistência } \\
\text { de separação } \\
\text { de poderes. }\end{array}$ & $\begin{array}{l}\text { Confusão entre poder } \\
\text { público e privado. } \\
\text { Capitães-donatários. } \\
\text { Guarda Real de Polícia da } \\
\text { Corte Portuguesa (1762). } \\
\text { Intendência-Geral de } \\
\text { Polícia da Corte (1808). } \\
\end{array}$ & $\begin{array}{l}\text { Índios, } \\
\text { escravos, } \\
\text { invasores } \\
\text { estrangeiros, } \\
\text { perseguidos } \\
\text { religiosos, } \\
\text { prostitutas. }\end{array}$ \\
\hline Império & 1824 & $\begin{array}{l}\text { Estado de exceção } \\
\text { misto }\end{array}$ & $\begin{array}{l}\text { Poder } \\
\text { moderador. } \\
\text { Decreto de } \\
1830 \text { contra } \\
\text { escravos } \\
\text { fugitivos. }\end{array}$ & $\begin{array}{l}\text { Corpo de Guardas } \\
\text { Municipais Permanentes. } \\
\text { Centralização do aparato } \\
\text { repressivo. Perda de poder } \\
\text { punitivo por parte dos } \\
\text { senhores de escravos. Casa } \\
\text { de Correção (1850). }\end{array}$ & $\begin{array}{c}\text { Escravos, } \\
\text { capoeiras, } \\
\text { militares } \\
\text { insurretos, } \\
\text { movimentos } \\
\text { insurrecionais, } \\
\text { prostitutas, } \\
\text { classes pobres. }\end{array}$ \\
\hline $\begin{array}{l}\text { República } \\
\text { Velha }\end{array}$ & 1891 & $\begin{array}{l}\text { Estado de exceção } \\
\text { misto }\end{array}$ & $\begin{array}{l}\text { Intervenções } \\
\text { federais nos } \\
\text { estados. }\end{array}$ & $\begin{array}{l}\text { Federalismo dual. } \\
\text { Policiamento repressivo do } \\
\text { espaço urbano. Controle } \\
\text { das polícias civis e } \\
\text { militares pelos governos } \\
\text { estaduais. Milícias } \\
\text { privadas do coronelismo. }\end{array}$ & $\begin{array}{c}\text { Comunistas, } \\
\text { socialistas, } \\
\text { anarquistas, } \\
\text { malandros, } \\
\text { vagabundos, } \\
\text { ex-escravos, } \\
\text { prostitutas, } \\
\text { classes pobres. }\end{array}$ \\
\hline Era Vargas & $1934 / 1937$ & $\begin{array}{l}\text { Estado de exceção } \\
\text { propriamente dito }\end{array}$ & $\begin{array}{c}\text { Lei de } \\
\text { segurança } \\
\text { nacional, } \\
\text { decretos-lei do } \\
\text { Estado novo }\end{array}$ & $\begin{array}{l}\text { Ascendência da polícia } \\
\text { civil. Centralização do } \\
\text { aparato policial pelo Poder } \\
\text { Executivo Federal. }\end{array}$ & $\begin{array}{l}\text { Comunistas, } \\
\text { anarquistas, } \\
\text { socialistas, } \\
\text { vagabundos, } \\
\text { judeus, } \\
\text { prostitutas, } \\
\text { classes pobres. }\end{array}$ \\
\hline $\begin{array}{c}\text { Período } \\
\text { democrático }\end{array}$ & 1946 & $\begin{array}{l}\text { Estado de exceção } \\
\text { misto }\end{array}$ & & $\begin{array}{l}\text { Restabelecimento das } \\
\text { garantias suplantadas pelo } \\
\text { Estado Novo. Retorno da } \\
\text { competência estadual } \\
\text { sobre as polícias. }\end{array}$ & $\begin{array}{l}\text { Recuo da } \\
\text { perseguição } \\
\text { político- } \\
\text { ideológica. } \\
\text { Classes pobres, } \\
\text { prostitutas, } \\
\text { vagabundos. }\end{array}$ \\
\hline $\begin{array}{c}\text { Ditadura } \\
\text { Militar }\end{array}$ & 1967/EC 1969 & $\begin{array}{l}\text { Estado de exceção } \\
\text { propriamente dito }\end{array}$ & $\begin{array}{c}\text { Atos } \\
\text { institucionais }\end{array}$ & $\begin{array}{l}\text { Doutrina de segurança } \\
\text { nacional. Ascendência das } \\
\text { Forças Armadas. DOI- } \\
\text { CODIs. Grupos de } \\
\text { extermínio. }\end{array}$ & $\begin{array}{c}\text { Comunistas, } \\
\text { anarquistas, } \\
\text { socialistas, } \\
\text { traficantes, } \\
\text { militantes } \\
\text { camponeses, } \\
\text { classes pobres, } \\
\text { prostitutas. }\end{array}$ \\
\hline $\begin{array}{c}\text { Transição/ } \\
\text { Neoliberalis } \\
\text { mo }\end{array}$ & 1988 & $\begin{array}{l}\text { Estado de exceção } \\
\text { misto (exceção } \\
\text { permanente) }\end{array}$ & $\begin{array}{l}\text { Lei de drogas. } \\
\text { Estado de } \\
\text { exceção não- } \\
\text { normado } \\
\text { (difuso) }\end{array}$ & $\begin{array}{c}\text { Política de guerra às } \\
\text { drogas. Ascendência da } \\
\text { polícia militar. Segurança } \\
\text { pública belicista. Milícias } \\
\text { urbanas e rurais. }\end{array}$ & $\begin{array}{c}\text { Traficantes, } \\
\text { militantes } \\
\text { camponeses, } \\
\text { classes pobres } \\
\text { (em especial } \\
\text { favelados), } \\
\text { prostitutas. } \\
\end{array}$ \\
\hline
\end{tabular}

Tabela 1: Proposição de quadro cronológico do estado de exceção na história brasileira. 
A tabela apresentada informa de maneira concisa as diversas fases do estado de exceção perpetradas no Estado brasileiro desde sua colonização. Mas é necessário aprofundar brevemente o debate em alguns pontos.

\subsubsection{Brasil Colônia}

A colonização do Brasil foi extremamente brutal. Houve um genocídio da população indígena conforme aponta o antropólogo brasileiro, Darcy Ribeiro:

(...) a população original do Brasil foi drasticamente reduzida por um genocídio de projeções espantosas, que se deu através da guerra de extermínio, do desgaste do trabalho escravo e da virulência das novas enfermidades que os achacaram. A ele se seguiu um etnocídio igualmente dizimador, que atuou através da desmoralização pela catequese; da pressão dos fazendeiros que iam se apropriando de suas terras; do fracasso de suas próprias tentativas de encontrar um lugar e um papel no mundo dos "brancos"16.

Quanto aos negros introduzidos no Brasil durante os três séculos de tráfico negreiro, pode-se dizer que esses exerceram papel fundamental na formação do nosso Estado, contudo, sofreram cruelmente com as práticas de controle social e, vale dizer, seus descendentes ainda sofrem nos dias de hoje.

Índios e negros, de modos distintos, eram as populações marginalizadas daquela época, viviam na condição de homo sacer $^{17}$, eram considerados seres matáveis. Observa-se aqui, que suas condições não advinham da contradição de textos legais, a exceção devia-se exclusivamente à distinção entre humanos e não-humanos ${ }^{18}$. A eles era

\footnotetext{
${ }^{16}$ RIBEIRO, Darcy. O povo brasileiro: a formação e o sentido do Brasil. São Paulo: Companhia das Letras, 1995 , p. 144.

17 AGAMBEN, Giorgio. Homo Sacer: o poder soberano e a vida nua. Belo Horizonte: Editora UFMG, 2002.

18 SOUZA, Taiguara Libano Soares. Constituição, Segurança Pública e Estado de Exceção Permanente: A Biopolítica dos Autos de Resistência. 2010. 217 p. Dissertação de Mestrado Departamento de Direitoda Pontifícia Universidade Católica do Rio de Janeiro, Rio de Janeiro, p. 50 .
} 
negado a humanidade e "concedido" o emprego da violência estatal ${ }^{19}$ a fim de controlá-los e puni-los.

Além disso, vale ressaltar, que a utilização da mão-de-obra escrava era concebida por muitos senhores do engenho, e por parte da elite europeia como um direito natural. Ou seja, a escravidão não foi criada ou positivada pela Coroa, ela era a mais pura expressão da exceção, haja vista que não era produzida por $1 \mathrm{ei}^{20}$.

\subsubsection{Constituição de 1824}

Com a promulgação da Constituição de 1824, que trazia em seu bojo diversas garantias fundamentais, a realidade acima descrita não se alterou, já que a maior parte da população brasileira, composta por negros e índios, não foi contemplada por essas garantias. Deste modo, pode-se afirmar que o texto constitucional não passava de letra morta.

Em contrapartida, apesar de a população negra não ser considerada humana e, consequentemente, não possuir direitos civis e políticos sendolhes, portanto, negado o status de sujeitos de direito, tal lógica não se aplicava à esfera penal, uma vez que esses indivíduos podiam ser criminalizados por crimes de insurreição, previstos pelo Código Criminal do Império de 1830 apenas quando praticados por escravos. Ademais, também era prevista "a pena de morte ao escravo que cometesse qualquer delito contra o senhor, o feitor ou seus familiares ${ }^{21}$,", segundo lei datada de 1835. Portanto, vê-se que o princípio da isonomia inscrito na Constituição Federal de 1824 não era observado.

\footnotetext{
${ }^{19} \mathrm{O}$ exercício do controle social, da segurança interna, era relegado aos donatários das sesmarias, que possuíam competência para julgar, condenar, punir e até mesmo executar dentro de sua "jurisdição". (Ibid. p. 53). Esta confusão entre público e privado no exercício do controle social pode ser verificada ainda hoje, através dos grupos de extermínio que são, geralmente, compostos por agentes estatais. Ademais, é também possível constatar a perpetuação da política de controle social extremamente repressiva por parte do Estado.

${ }^{20}$ Ibid, p. 58.

${ }^{21}$ Ibid, p. 57.
} 
Importa observar que, nessa época, a polícia já havia sido criada e estava com a sua atenção voltada para as chamadas classes perigosas, ou seja, escravos, negros libertos e pobres livres. Sua atividade, basicamente, consistia em capturar escravos fugitivos, reprimir insurreições populares e agir de forma repressiva aos crimes patrimoniais, à vadiagem e à prática de capoeira $^{22}$.

Logo, como se pode constatar, a polícia desde sua origem já tinha um caráter repressivo e sua função destinava-se ao controle da ordem social, principalmente das camadas mais pobres, defendendo, desse modo, o interesse daqueles que detinham o poder.

\subsubsection{República Velha}

Quando a República Velha foi proclamada em 1889, o Brasil já havia promulgado a abolição da escravatura, portanto, esperava-se que, em relação aos direitos sociais, o Brasil teria evoluído de algum modo. Não é, porém, o que se observa desse período. Contrariando as expectativas, a Carta Política de 1891 não acompanha nenhum movimento de legitimação social, apenas faz mudanças formais, mostrando-se silente no que diz respeito às demandas sociais.

O cenário político, social e econômico da época encontrava-se instável, favorecendo uma série de revoltas populares, às quais o Estado brasileiro respondeu de maneira violenta e autoritária, sempre buscando oprimir e marginalizar a classe social mais pobre, que já se encontrava excluída.

De acordo com o exposto por Taiguara, o pensamento positivista teve forte influência sobre a República Velha, inclusive, na adoção dos dizeres "Ordem e Progresso" na bandeira pátria. Para o autor, elas fortalecem a ideia de opressão. Segundo ele, "Ordem para controlar e vigiar as massas

\footnotetext{
${ }^{22}$ Ibid, p. 63.
} 
oprimidas e exploradas, e progresso econômico à burguesia nacional incipiente ${ }^{23,}$.

Nesse sentido, o Código Penal promulgado em 1890 prevê uma série de novos crimes, todos com a finalidade de criminalizar a pobreza, já que a criminologia que embasava o novo ordenamento centrava-se na figura do autor e não no fato criminoso ${ }^{24}$. $\mathrm{O}$ controle social tinha agora uma nova roupagem:

fábricas-prisões para menores aprenderem o trabalho (...); prisões curtas, com compromisso de "tomar ocupação" logo após, ou, na reincidência, remoções para colônias penais nas ilhas marítimas ou nas fronteiras, para vadios, mendigos e "capoeiras" (se estrangeiros, posterior deportação); privação da liberdade para homens livres que cometessem algum crime. A equação estava montada: fábrica ou cárcere $^{25}$.

O controle repressivo, como já abordado em outro momento, ficava a cargo dos policiais militares que, investidos de amplos poderes e discricionariedade no exercício da profissão, tinham dificuldade em cumprir a lei e zelar pela manutenção da ordem, fazendo uso com frequência de medidas arbitrárias e violentas.

Cumpre salientar que, nesse período, houve uma reorganização das forças policiais. As polícias civis e militares passaram a responder aos governadores dos estados. Contudo, isso não significou o fim da influência política dos coronéis locais nas polícias, mas evidenciou que essa influência derivava de acordos políticos entre a capital e o respectivo município ${ }^{26}$.

\footnotetext{
${ }^{23}$ Ibid, p. 65.

${ }^{24}$ Passados mais de cem anos é possível observar que tal modo de compreender o sistema penal não sofreu grandes modificações. O atual Código Penal brasileiro, por exemplo, fundamenta-se, basicamente, em crimes patrimoniais, crimes que, em rigor, são praticados por apenas uma camada específica da população (a mais pobre, que muitas vezes não tem recursos para a sua própria subsistência). Logo, é o sistema penal que fundamentou e fundamenta a opressão histórica das classes subalternas. Ademais, nossos Tribunais ainda julgam a moralidade daqueles que praticam crimes, suas vidas pregressas e não o fato criminoso que cometeram.

${ }^{25}$ BATISTA, Nilo. Punidos e mal pagos: violência, justiça, segurança pública e direitos humanos no Brasil de hoje. Rio de Janeiro: Revan, 1990, p. 125.

${ }^{26}$ SOUZA, Taiguara Libano Soares. Constituição, Segurança Pública e Estado de Exceção Permanente: A Biopolítica dos Autos de Resistência. 2010. 217 p. Dissertação de Mestrado Departamento de Direitoda Pontifícia Universidade Católica do Rio de Janeiro, Rio de Janeiro, p. 67.
} 


\subsubsection{Era Vargas}

Em consequência direta da Revolução Constitucionalista de 1932 e sob grande influência da Constituição Alemã de Weimar a Constituição de 1934 foi promulgada.

A Carta Magna foi bastante progressista, trazendo em seu texto direitos políticos e sociais - esse último composto, principalmente, por direitos trabalhistas -, além de ter confirmado o federalismo do Brasil, ou seja, a autonomia dos estados perante a União. Grande parte desses direitos, porém, ficaram adstritos à folha de papel e não foram postos em prática.

O cenário político ia em direção oposta ao que apontava a Carta. Havia uma forte tendência global antiliberal em nome da autoridade da nação, vide a ascensão nazista na Alemanha e o Fascismo na Itália, por exemplo. Getúlio Vargas, em seu governo, não agiu de modo contrário à situação que se apresentava no restante do mundo. Ele agiu em conformidade, acentuando a centralização do poder, o que culminou, em 1937, no Estado Novo, regime caracterizado pelo autoritarismo.

Nessa conjuntura, a polícia teve papel fundamental, pois também coube à instituição policial o controle de grupos que eram vistos como inimigos do Estado, tais como: judeus, comunistas e dissidentes políticos. Eles deveriam ser controlados e vigiados do mesmo modo que as demais classes tidas como perigosas já eram ${ }^{27}$.

Importa salientar que a atuação repressora da polícia tornou-se mais "legítima" e ampla após a promulgação do Decreto no 24.531 em 1934 e da aprovação da Lei de Segurança Nacional em 1935. Para além disso, é importante destacar que a Constituição de 1934 declarou que as polícias

\footnotetext{
${ }^{27}$ Ibid, p. 68.
} 
eram forças de reserva do exército ${ }^{28}$ e assegurou a competência exclusiva da União para legislar acerca do tema.

O Estado Novo foi um regime autoritário, como já comentado anteriormente, tendo sua Carta política apenas ratificado tal situação. Vale lembrar, inclusive, que seu artigo 186 declarava "em todo o País o estado de emergência". Aqui é possível notar o conceito apresentado por Schmitt de que o "soberano é quem decide sobre o estado de exceção ${ }^{29}$ ", tendo em vista que o então chefe do Poder Executivo, Getúlio Vargas, não só decretou o estado de emergência como também passou a governar através de decretos.

A polícia civil, sob a égide desse novo ordenamento, teve um papel substancial para o aparato estatal: ficou a seu cargo realizar os serviços de inteligência do regime e a repressão dos opositores.

Foi possível conseguir certo fôlego por meio da promulgação da Constituição de 1946, pois, a partir dela, passou a ser concebível pensar em um Estado democrático. Tal Carta política sofreu influência da Constituição Francesa e da Constituição Alemã de Weimar, a mesma que já havia influenciado a Constituição de 1934 com princípios de ordem social e econômica.

A nova Carta restabeleceu, em seu texto, direitos e garantias individuais que haviam sido ceifadas durante o Estado Novo - algumas destas garantias estão previstas atualmente no artigo $5^{\circ}$ da Constituição da República Federativa do Brasil de 1988.

\subsubsection{Ditadura Militar de 1964}

O golpe militar deflagrou-se na madrugada do dia 31 de março de 1964 , e no dia $1^{\circ}$ de abril do mesmo ano estava instaurado o que veio a ser

\footnotetext{
${ }^{28}$ Esse texto nunca foi revogado, tanto que atualmente as polícias militares, bem como, os bombeiros militares, seguem sendo forças auxiliares do exército, conforme prevê o art. $144, \S 6^{\circ} \mathrm{da}$ Constituição Cidadão de 1988.

${ }^{29}$ SCHMITT, Carl. Teologia política. Belo Horizonte: Del Rey, 2006, p. 7.
} 
um dos períodos mais violentos da história brasileira devido às graves violações de direitos humanos perpetradas pelo Estado.

A ditadura compreendeu o período entre 1964 a 1985. Ao longo desse tempo foram elaborados dezessete Atos Institucionais ${ }^{30}$. O primeiro deles, instaurado no dia 9 de abril de 1964, modificou a Constituição de 1946, ainda vigente, e criou uma normatividade paralela a ela, conferindo aos comandantes-em-chefe das Forças Armadas o poder de suspender direitos políticos e cassar mandatos legislativos ${ }^{31}$. Vale ressaltar que fora invocado o poder constituinte originário para reivindicar a legitimidade da ação com intuito de que ela não fosse reconhecida como golpe, e sim como revolução.

Através dos Atos Institucionais e, posteriormente, da Constituição de 1967 e da Emenda Constitucional no 01 de 1969, é possível verificar que houve a positivação do estado de exceção. Portanto, esse período pode ser classificado na categoria "estado de exceção propriamente dito" proposta por Vieira $^{32}$, indo em direção contrária à regra da trajetória brasileira, que sempre foi de não normatizar o estado de exceção ${ }^{33}$, sendo sempre realizado "por baixo dos panos".

No ano de 1967 foi decretada a Lei de Segurança Nacional ${ }^{34}$, que definiu crimes contra a segurança nacional e contra a ordem política e social. Heleno Fragoso, um dos mais importantes advogados de presos políticos na época da ditadura militar, afirma que com a instauração do decreto:

\footnotetext{
${ }^{30}$ Editados pelos Comandantes-em-Chefe do Exército, da Marinha e da Aeronáutica ou pelo Presidente da República, com o respaldo do Conselho de Segurança Nacional.

${ }^{31}$ Ato Institucional ${ }^{\circ} 1$, de 09 de abril de 1964 - Art. 10 - No interesse da paz e da honra nacional, e sem as limitações previstas na Constituição, os Comandantes-em-Chefe, que editam o presente Ato, poderão suspender os direitos políticos pelo prazo de dez (10) anos e cassar mandatos legislativos federais, estaduais e municipais, excluída a apreciação judicial desses atos.

Parágrafo único - Empossado o Presidente da República, este, por indicação do Conselho de Segurança Nacional, dentro de 60 (sessenta) dias, poderá praticar os atos previstos neste artigo.

32 VIEIRA, José Ribas. O autoritarismo e a Ordem Constitucional no Brasil. Rio de Janeiro: Renovar, 1988, p. 46.

${ }^{33}$ SOUZA, Taiguara Libano Soares. Constituição, Segurança Pública e Estado de Exceção Permanente: A Biopolítica dos Autos de Resistência. 2010. 217 p. Dissertação de Mestrado Departamento de Direitoda Pontifícia Universidade Católica do Rio de Janeiro, Rio de Janeiro, p. 73.

${ }^{34}$ Decreto-Lei no 314 , de 13 de março de 1967.
} 
objeto de proteção jurídica passam a ser certos objetivos nacionais permanentes, entre os quais se incluem a paz pública e a prosperidade nacional, elementos que levam a confundir a criminalidade comum com a criminalidade política ${ }^{35}$.

Salienta-se, ainda, que a competência para julgar os crimes dispostos no decreto foi concedido à Justiça militar. Acerca disso, Fragoso também tece alguns comentários:

Embora se possa dizer que a Justiça Militar passou a julgar todos esses delitos em função da ideia de guerra interna, convém observar que as limitações da justiça ordinária para o julgamento de crimes políticos têm acompanhado invariavelmente situações de perturbação política intensa e estados de emergência. A nossa antiga lei de segurança (Lei $\mathrm{n}^{\mathrm{o}} 1.802$, de 05 de janeiro de 1953) também previa a competência da Justiça Militar para julgamento dos crimes contra a segurança externa, e nada tinha a ver com a doutrina da segurança nacional. A verdade é que a competência da Justiça Militar para o julgamento dos crimes contra a segurança interna foi introduzida em nosso ordenamento jurídico com o Ato Institucional $n^{\circ} 2$ (art. $8^{\circ}$ ), em 27 de outubro de 1965, como reação ao comportamento dos tribunais civis, notadamente o Supremo Tribunal Federal, no julgamento de pessoas acusadas de crimes políticos. O fato constituiu fenômeno comum nos movimentos políticos, que procuram introduzir severidade na pretensão punitiva revolucionária ${ }^{36}$.

Logo, é possível concluir que o efeito do decreto foi devastador para as liberdades individuais dos brasileiros, principalmente, daqueles que se colocaram contrários ao regime.

Em dezembro de 1968 foi instaurado o AI $5^{37}$, considerado por muitos como o golpe dentro do golpe, a exceção dentro da exceção. Inclusive, no dia que seguinte à sua instauração, o "Jornal do Brasil" com o

\footnotetext{
${ }^{35}$ FRAGOSO, Heleno Cláudio. A nova lei de segurança nacional. In Revista de Direito Penal de Criminologia, jan/jun. 1983, $\mathrm{n}^{\circ}$ 35. Rio de Janeiro: Forense, p. 60-69. Disponível em: 〈http://www.planalto.gov.br/ccivil_03/revista/Rev_58/panteao/HelenoClaudioFragoso.pdf〉. Acesso em 12.05.2015.

${ }^{36}$ Ibid.

${ }^{37}$ Dentre as medidas excepcionais autorizadas pelo AI 5, encontram-se: fechar o Congresso Nacional e outros legislativos (medida regulamentada pelo Ato Complementar $\mathrm{n}^{\circ} 38$ ), cassar mandatos eletivos, suspender por dez anos os direitos políticos de qualquer cidadão, intervir em Estados e municípios, decretar confisco de bens por enriquecimento ilícito e suspender o direito de habeas corpus para crimes políticos, impor a censura para os meios de comunicação, além de dar outras providências.
} 
intuito de informar os acontecimentos à população publica na sua seção de meteorologia, para driblar a censura, o que segue:

Previsão do tempo:

Tempo negro.

Temperatura sufocante.

O ar está irrespirável.

O país está sendo varrido por fortes ventos.

Máx.: $38^{\circ}$, em Brasília. Mín.:5º nas Laranjeiras. ${ }^{38}$

O ano de 1968 também foi marcado pelo início da luta armada contra a ditadura, o que resultou no aumento da repressão estatal. As torturas e perseguições se intensificaram, sendo o massacre do Araguaia o caso mais emblemático.

A repressão provocada pelo estado de exceção formal no Brasil ditadura militar - produziu uma série de vítimas. Houve torturas, desaparecimentos forçados, homicídios, perseguições, prisões, sequestros, banimentos e exilamentos. Todas estas violações de direitos humanos por parte do Estado não foram até hoje, na sua totalidade, esclarecidas ${ }^{39}$.

A essas vítimas é possível aplicar o conceito de homo sacer de mera vida nua matável, trabalhado por Agamben ${ }^{40}$, tendo em vista que seus direitos e garantias foram suspensos a um nível extremo, ao ponto de suas vidas poderem ser ceifadas pelos agentes estatais e estes não sofrerem qualquer responsabilização ${ }^{41}$. Pelo contrário, a atividade repressiva era

\footnotetext{
${ }^{38}$ <http://www1.folha.uol.com.br/folha/treinamento/hotsites/ai5/ai5/>. Acesso em 14.05.2015.

${ }^{39}$ A Comissão Nacional da Verdade criada pela Lei 12.528/2011 e instituída em maio de 2012 foi criada com a finalidade de apurar graves violações de Direitos Humanos ocorridas entre 18 de setembro de 1946 e 05 de outubro de 1988. Em 10 de dezembro de 2014 a CNV entregou seu relatório final dividido em três volumes, resultado de dois anos e sete meses de trabalho. $<$ http://www.cnv.gov.br/index.php/outros-destaques/574-conheca-e-acesse-o-relatorio-final-dacnv>. Acesso em 14.05.2015.

Ocorre que é improvável que nesse curto período (dois anos e sete meses) a Comissão tenha conseguido esclarecer todas as violações ocorridas no espaço temporal que ela se propôs apurar.

${ }^{40}$ AGAMBEN, Giorgio. Homo Sacer: o poder soberano e a vida nua. Belo Horizonte: Editora UFMG, 2002.

${ }^{41}$ Como apontado na sequência, no contexto em que tais violações ocorreram elas eram consideradas legítimas, portanto o Estado não as condenava, bem como também não as desautorizava. Posteriormente, o Brasil promulgou a Lei da Anistia (Lei $n^{\circ}$ 6.683, de 1979), considerada ampla, geral e irrestrita que beneficiou, inclusive, os agentes estatais que praticaram graves violações contra os direitos humanos.
} 
considerada lícita e aceitável, com a justificativa de que tal aniquilação era admitida, pois visava à restauração da ordem e da segurança nacional, considerado um "bem maior".

$\mathrm{O}$ aparato repressivo da ditadura militar, contrariamente ao que ocorreu na ditadura Vargas, ficou sob a responsabilidade das Forças Armadas, que detinham o "monopólio da coerção político-ideológica", mas, não do aparato policial. Enquanto isso, às polícias militares coube o patrulhamento ostensivo das cidades, o que foi facilitado após as GuardasCivis serem incorporadas à $\mathrm{PM}^{43}$.

Em abril de 1977, foi transferida para a Justiça militar a competência de julgar policiais militares acusados pela prática de crimes efetuados contra civis. Com essa medida, o caráter militar da polícia foi ainda mais acentuado e ela passou a ter mais liberdade para perpetrar os crimes, pois de certo modo, havia a garantia de que não seria responsabilizada.

Importa dizer que o aparato repressivo era composto por uma série de órgãos, alguns preexistentes à ditadura militar, outros criados após o golpe de modo a consolidar uma estrutura única e coesa.

Em 1964 foi criado o Serviço Nacional de Informações (SNI) ${ }^{44}$, diretamente ligado à Presidência da República e que tinha como finalidade superintender e coordenar as atividades de informação ${ }^{45}$.

Acerca do tema é importante observar a sentença da Corte Interamericana de Direitos Humanos (CIDH) que responsabilizou internacionalmente o Brasil pelo desaparecimento de cerca de 70 pessoas, entre os anos de 1972 e 1974, caso conhecido como Guerrilha do Araguaia.

${ }^{42}$ COSTA, Arthur Trindade Maranhão. Entre a lei e a ordem: violência e reforma nas polícias do Rio de Janeiro e Nova York. Rio de Janeiro: Editora FGV, 2004, p. 97.

43 SOUZA, Taiguara Libano Soares. Constituição, Segurança Pública e Estado de Exceção Permanente: A Biopolítica dos Autos de Resistência. 2010. 217 p. Dissertação de Mestrado Departamento de Direitoda Pontifícia Universidade Católica do Rio de Janeiro, Rio de Janeiro, p. 75.

${ }^{44}$ Lei $\mathrm{n}^{\circ} 4.341$, de 13 de julho de 1964.

45 Entre as suas atribuições destacava-se a função de "estabelecer ligação direta com órgãos federais, estaduais e municipais e com entidades paraestatais e autarquias", além de poder "requisitar a colaboração de entidades privadas". Vale salientar, que o SNI incorporou o Serviço Federal de Informações e Contra-Informações (SFICI), inclusive todos os funcionários civis e militares que nele exerciam funções. <http://www.abin.gov.br/modules/mastop_publish/?tac=142> . Acesso em 13.05.2015. 
Em 1970, foram criados o Destacamento de Operações de Informação (DOI), responsável pelas ações práticas de busca, apreensão e interrogatório de suspeitos - e o Centro de Operações de Defesa Interna (CODI), cujas funções abrangiam a análise de informações, a coordenação dos diversos órgãos militares, o planejamento estratégico do combate aos grupos de esquerda e a burocracia. Eram órgãos distintos, porém frequentemente associados, sendo chamados de DOI-CODI.

Havia também uma série de centros clandestinos de tortura e assassinato criados e mantidos pelos órgãos de repressão estatal, sendo a Casa da Morte situada em Petrópolis/RJ, um dos únicos locais que se tornou conhecido devido à denuncia feita por Inês Etienne Romeu ${ }^{46}$, a única sobrevivente do lugar.

A casa, que pertencia a um particular, foi cedida ao Centro de Informações do Exército. Paulo Malhães, que integrou o CIE, relata em depoimento concedido a Comissão Estadual da Verdade do Rio de Janeiro, em maio de 2013, ter sido um dos mentores da Casa da Morte, considerada

\footnotetext{
${ }^{46}$ Segundo o que consta em relatórios, carta e documentos entregues a OAB/RJ em setembro de 1979, acrescido do depoimento de Inês Etienne concedido ao Conselho Federal da Ordem dos Advogados do Brasil no mesmo ano, Inês foi barbaramente torturada (pau-de-arara, espancamentos, choques elétricos na cabeça, pés e mãos) quando "interrogada" no Departamento de Ordem Política e Social - DOPS/SP, posteriormente tentou suicidar-se para evitar novas torturas, contudo não obteve sucesso, sendo levada para o Hospital da Vila Militar e depois para o Hospital Central do Exército para receber cuidados médicos. Em seguida foi levada à Casa da Morte, localizada em Petrópolis/RJ, onde ficou três meses passando por torturas físicas e psicológicas que incluíam espancamentos, estupros, humilhações, drogas injetadas (pentotal sódico - soro da verdade), choques elétricos na cabeça, pés, mãos e seios. Como Inês mesmo definiu ela foi "submetida a verdadeiro horror" e por isso tentou, por quatro vezes, suicidar-se. Passado o período de torturas físicas, Inês, para tentar sair do cárcere clandestino, mentiu alegando que colaboraria com os agentes. Ao chegar em Belo Horizonte/MG Inês foi internada na Clínica Pinel e, posteriormente, transferida para a Casa de Saúde Santa Maria, em razão das condições precárias de saúde em que encontrava-se, nesses locais sofreu diversas ameaças de morte e de condenação a prisão perpétua. Três meses depois sua prisão foi oficializada, após seu advogado, Augusto Sussekind, ter pleiteado por diversas vezes perante a Terceira Auditoria do Exército, com o intuito de que a prisão de Inês perdesse o caráter clandestino que, até então, estava presente. Inês ficou presa até 1979 e em muitos momentos sofreu ameaças sob a recomendação de que não denunciasse as violências sofridas e/ou os fatos presenciados.

Inês Etienne Romeu faleceu em abril de 2015, vítima de infarto. <http://odia.ig.com.br/noticia/riode-janeiro/2015-04-28/ines-etienne-romeu-uma-historia-de-luta-contra-a-tortura.html>. Acesso em 16.05.2015.
} 
por ele um "laboratório clandestino fora dos espaços militares, que permitia uma atuação mais livre e mais violenta em seu aspecto psicológico ${ }^{47, "}$

Em 1974 assume a presidência o general Ernesto Geisel, articulador de um projeto de abertura política "lenta, gradual e segura", que só veio a ser concretizado anos mais tarde. Contudo, embora a distensão tenha sido lenta e gradual, não foi segura.

No final do seu governo, em função da pressão internacional e do crescimento da oposição, Geisel coibiu formalmente a utilização de técnicas de tortura pelas tropas militares e revogou os Atos Institucionais e os Atos Complementares por meio da Emenda Constitucional nº 11 de 1978.

Grande parte do aparato repressivo excepcional do regime militar foi desmontado no momento da transição política entre ditadura e democracia. Porém, no que diz respeito às Polícias, essas mantiveram boa parte da estrutura que existia. Além disso, a Constituição Cidadã de 1988 conservou os vínculos formais entre a Polícia e o Exército, o que reforçou a militarização nas políticas de segurança pública ${ }^{48}$.

Em 1979 foi promulgada, pelo então presidente João Figueiredo, a Lei da Anistia ${ }^{49}$. O Brasil estava dando o primeiro passo em direção ao esquecimento, principalmente no que concerne às implicações jurídicas das torturas, dos desaparecimentos forçados e dos demais abusos cometidos pelo Estado.

O processo de redemocratização que ocorreu a partir da década de 80, estava entranhado do autoritarismo dos anos de chumbo e foi seguido por uma crise de estatalidade. Havia territórios onde a presença do Estado era quase imperceptível, dando ensejo a poderes paralelos, como grupos armados do comércio de drogas ilegais e milícias paramilitares. O Estado passou a coexistir com essas esferas de poder autônomas, interagindo com

\footnotetext{
$47<$ http://www.cev-rio.org.br/wp-content/uploads/2014/05/depoimentomalhaes.pdf $>$. Acesso em 16.05.2015.

${ }^{48}$ D'ARAÚJO, Maria Celina e CASTRO, Celso (orgs.). Ernesto Geisel. Rio de Janeiro: Editora FGV, 1997, p. 474.

${ }^{49}$ Lei no $6.683,28$ de agosto de 1979.
} 
esses territórios apenas de maneira violenta no uso do aparato repressivo a fim de exercer o controle social. Nos demais momentos, esses territórios são largados ao acaso e as populações dotadas de uma "cidadania de baixa intensidade" $" 50$, ou seja, seus direitos e garantias mais básicos não são respeitados.

A partir desse cenário, é possível constatar que o Estado Democrático de Direito brasileiro convive perfeitamente com o Estado de exceção, sendo esse último, restrito a determinados territórios e camadas sociais.

\subsubsection{Constituição Cidadã de 1988}

A atual Carta Magna, também chamada de Constituição Cidadã, leva esse nome devido aos direitos e garantias fundamentais por ela acolhidos, que se encontram regulados entre os artigos $5^{\circ}$ e $17^{\circ}$ e estão reunidas em três gerações (1. individuais, civis e políticas; 2. sociais, econômicas e

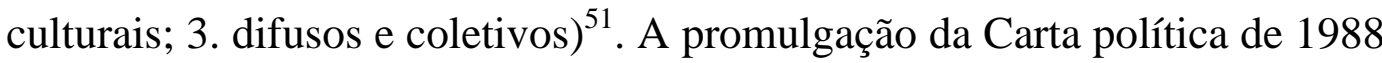
significou, para os brasileiros, um enorme avanço, um passo significativo para a democracia. Nas palavras de Ulysses Guimarães:

A Constituição mudou na sua elaboração, mudou na definição dos poderes, mudou restaurando a Federação, mudou quando quer mudar o homem em cidadão, e só é cidadão quem ganha justo e suficiente salário, lê e escreve, mora, tem hospital e remédio, lazer quando descansa. (...)

Tipograficamente é hierarquizada a precedência e a preeminência do homem, colocando-o no umbral da Constituição e catalogando-lhe o número não superado, só no art. $5^{\circ}$, de 77 incisos e 104 dispositivos.

Não lhe bastou, porém, defendê-lo contra os abusos originários do Estado e de outras procedências. Introduziu o homem no Estado, fazendo-o credor de direitos e serviços, cobráveis inclusive com o mandado de injunção ${ }^{52}$.

\footnotetext{
${ }^{50}$ SOUZA, Taiguara Libano Soares. Constituição, Segurança Pública e Estado de Exceção Permanente: A Biopolítica dos Autos de Resistência. 2010. 217 p. Dissertação de Mestrado Departamento de Direitoda Pontifícia Universidade Católica do Rio de Janeiro, Rio de Janeiro, p. 81.

${ }^{51}$ MENDES, Gilmar Ferreira; COELHO, Inocêncio Mártires; BRANCO, Paulo Gustavo Gonet. Curso de Direito Constitucional. São Paulo: Saraiva, 2010, p. 309/310.

${ }^{52}$ Discurso do então Presidente da Assembleia Constituinte, Ulysses Guimarães, proferido no dia 05 de outubro de 1988, na promulgação da Carta Política de 1988. Disponível em: <http://www2.camara.leg.br/atividade-legislativa/plenario/discursos/escrevendohistoria/25-anos-
} 
Entretanto, apenas uma parcela da população brasileira foi contemplada por esses direitos e garantias na sua totalidade. Para as classes e grupos sociais oprimidos, para os invisíveis, os excluídos sociais, a realidade é bem diversa. A eles o status de "cidadão" não foi "concedido". Para esses, que vivem em determinado território do espaço rural e urbano, o Estado de Direito não foi restabelecido, continuam a viver em um estado de exceção permanente.

O Brasil, a partir de 1988, pode ser então classificado como um “Estado de exceção híbrido", conforme as categorias propostas por Vieira ${ }^{53}$. Ou seja, é um Estado dotado de avanços democráticos, contudo com medidas governamentais de padrões autoritários ${ }^{54}$.

Vive-se, atualmente, o maior período de vida democrática ininterrupta da história do Brasil. Porém, nunca se conviveu de modo tão passivo com os traços de autoritarismo e com as violações aos direitos civis e humanos que ocorrem no cotidiano das cidades brasileiras. Diariamente, os direitos mais basilares são desrespeitados nos territórios marginalizados, onde o Estado somente se faz presente para garantir a ordem social, no entanto não garante direitos sociais, civis, econômicos e culturais.

Os meios de comunicação de massa (formadores de opinião) são fundamentais para a manutenção desse cenário, visto que os mesmos garantem, por meio da "inversão da realidade", da "produção da indignação moral" e/ou da "fabricação do estereótipo do criminoso",55 a naturalização das condutas autoritárias do Estado perante territórios e segmentos populacionais específicos.

da-constituicao-de-1988/constituinte-1987-1988/pdf/Ulysses\%20Guimaraes\%20-

\%20DISCURSO\%20\%20REVISADO.pdf $>$. Acesso em 16.05.2015.

${ }^{53}$ VIEIRA, José Ribas. O autoritarismo e a Ordem Constitucional no Brasil. Rio de Janeiro: Renovar, 1988, p. 46.

${ }^{54}$ SOUZA, Taiguara Libano Soares. Constituição, Segurança Pública e Estado de Exceção Permanente: A Biopolítica dos Autos de Resistência. 2010. 217 p. Dissertação de Mestrado Departamento de Direitoda Pontifícia Universidade Católica do Rio de Janeiro, Rio de Janeiro, p. 83.

${ }^{55}$ BATISTA, Vera Malaguti. Dificeis ganhos fáceis: drogas e juventude pobre no Rio de Janeiro. Rio de Janeiro: Revan, 2003, p. 56. 
Do mesmo modo, as mídias de massa também manipulam a sociedade pela difusão da sensação do medo, da insegurança e da impunidade, para que se acredite que o punitivismo ${ }^{56}$ é o instrumento ideal para o controle da criminalidade e da ordem social, acentuando, desse modo, o pensamento reacionário e elitista de toda a população, principalmente da parcela que, por não ter tido acesso à educação de

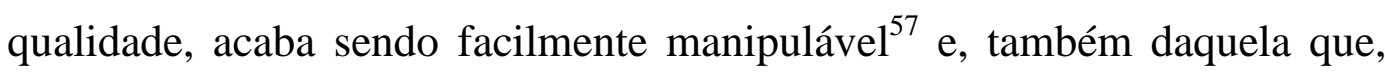
por motivos diversos, somente tem acesso a esses meios de comunicação ${ }^{58}$ e, portanto forma sua opinião a partir deles.

Há, ainda, a disseminação da ideologia de extermínio "bandido bom é bandido morto", que, mesmo quando não expressada diretamente, pode ser lida nas entrelinhas das publicações dos grandes jornais, nos editoriais das mídias de massa. O resultado disso é uma população raivosa e vingativa, que crê que os direitos humanos deveriam apenas existir e ser aplicado para "humanos direitos" $"$. Ou seja, desse modo a mídia naturaliza a ideia de que o Estado pode destituir determinados grupos de seus direitos fundamentais - como o direito a vida e à defesa; que o Estado pode abrir mão do princípio da isonomia de tratamento, preceituado no caput do art. $5^{\circ}$

\footnotetext{
${ }^{56} \mathrm{O}$ conceito de punitivismo é contrário ao princípio da intervenção mínima adotado pelo Direito Penal brasileiro, este último de acordo com Nucci significa que "O Direito Penal não deve interferir em demasia na vida do indivíduo, retirando-lhe autonomia e liberdade. Afinal, a lei penal não deve ser vista como a primeira opção (prima ratio) do legislador para compor conflitos existentes em sociedade e que, pelo atual estágio de desenvolvimento moral e ético da humanidade, sempre estarão presentes." - NUCCI, Guilherme de Souza. Manual do Direito Penal, - Parte Geral e Especial. São Paulo: RT, 2006, p. 69.

${ }^{57}$ Importa pontuar que extensa parcela da população segue na condição de analfabeto funcional. São cerca de 13 milhões de brasileiros, segundo a Pesquisa Nacional por Amostra de Domicílio PNAD, publicada em 2014 pelo Instituto Brasileiro de Geografia e Estatística - IBGE. $<$ http://agenciabrasil.ebc.com.br/educacao/noticia/2014-09/Analfabetismo-cai-0,4-pontospercentuais-mas-ainda-atinge-13-milh\%C3\%B5es>. Acesso em 17.05.2015.

${ }_{58}$ Parece improvável que isso possa ocorrer em pleno séc. XXI, visto que maior parte da população tem acesso a Internet e, portanto a conteúdos variados. Contudo, é necessário lembrar que o Brasil é um país continental e que no interior, nos locais mais longínquos, os meios de comunicação de massa, principalmente televisivos, continuam sendo o único meio informativo, quando não o único, o principal.

${ }^{59}$ Como bem exprimiu Nilo Batista "Direitos humanos são direitos que toda pessoa humana tem independente do que seja, tenha, pense ou faça". BATISTA, Nilo. Punidos e mal pagos: violência, justiça, segurança pública e direitos humanos no Brasil de hoje. Rio de Janeiro: Revan, 1990, p. 158.
} 
da Constituição Federal de $1988^{60}$; significa, ainda, dizer que a sociedade "abre mão" do Estado Democrático de Direito à parcela marginalizada da população que terá o Estado de exceção como regra em suas vidas.

É válido ressaltar que a revolta que nasce com o discurso "bandido bom é bandido morto" é seletiva. Recai sempre sobre as classes e grupos sociais oprimidos, excluídos e invisíveis da sociedade. Afinal, não é toda violência que choca e mobiliza esse discurso, é necessário que ela ocorra em espaços geográficos específicos e contra vítimas particulares.

A imprensa, ao associar condição social (pobre, morador da favela ou periferia), cor de pele (negros e pardos), idade (jovens) com violência e criminalidade, está fomentando o processo de criminalização da pobreza, está formulando o estereótipo do bandido. Sendo incluídos nessa rotulação todos que, de certo modo, não conseguem se inserir na ordem econômica. Nessa perspectiva, Alessandra de Andrade Rinaldi exprime:

Por "fugir ao padrão", apresenta-se como uma espécie de ameaça ao esquema classificatório de nossa estrutura social. Por não representar os valores "ideais" do padrão, passa a ser vista como algo a ser evitado, como perigosa. (...)

Como esse rótulo genérico é atribuído aos moradores indistintamente, todos eles são considerados perigosos (...).

Ser morador da favela é trazer a "marca do perigo", é ter uma identidade social pautada pela ideia da pobreza, miséria, crianças na rua, família desagregada, criminalidade, delinquência. Tais imagens são realimentadas pelos veículos de informação, que trazem notícias sobre o "morro" sempre do ponto de vista negativo, enfatizando o tráfico de drogas e a violência ${ }^{61}$.

Nesse sentido, é possível dizer que a exceção permanente torna-se ferramenta para a manutenção do status quo daqueles que são detentores do

\footnotetext{
${ }^{60}$ Caput do Art. $5^{\circ}$ da Constituição Federal: "Todos são iguais perante a lei, sem distinção de qualquer natureza, garantindo-se aos brasileiros e aos estrangeiros residentes no País a inviolabilidade do direito à vida, à liberdade, à igualdade, à segurança e à propriedade, nos termos seguintes:".

${ }^{61}$ RINALDI, Alessandra de Andrade. Marginais, delinquentes e vítimas: um estudo sobre a representação da categoria favelado no tribunal do júri da cidade do Rio de Janeiro. In ZALUAR, Alba \& ALVITO, Marcos (Orgs.). Um século de favela. Rio de Janeiro: Editora FGV, 2004, p. 306/307.
} 
poder. A não observância do direito, a sua suspensão e usurpação é a resposta imediata sempre que o poder soberano se sente ameaçado ${ }^{62}$.

Portanto, ao passo que para alguns o Estado se faz presente em todos os âmbitos (saúde, educação, segurança etc), outros somente o conhecem como uma figura repressora, devido à política de segurança pública adotada, principalmente, nas grandes cidades.

Logo, como se observa, o Estado Democrático de Direito dialoga com o Estado de exceção. Ambos convivem lado a lado.

No que concerne à Constituição de 1988, há alguns pontos que devem ser esclarecidos. Apesar dos ventos democráticos trazidos pela Carta política, a mesma manteve consigo alguns ares autoritários provenientes dos anos de chumbo. Conforme expõe Jorge Zaverucha:

A nova Constituição descentralizou poderes e estipulou importantes benefícios sociais similares às democracias mais avançadas. No entanto, uma parte da Constituição permaneceu praticamente idêntica à Constituição autoritária de 1967 e à sua emenda de 1969. Refiro-me às cláusulas relacionadas com as Forças Armadas, Polícias Militares estaduais, sistema judiciário militar e de segurança pública no geral ${ }^{63}$.

O texto constitucional ao tratar do tema de segurança pública manteve dispositivos de cunho autoritário como, por exemplo, o artigo $142^{64}$ que, em seu caput, faz referência a "lei e ordem". Além de ser uma expressão vaga, já que a própria Constituição não a define, bem como não estabelece as condições que configurariam a violação desse preceito, também deixa a cargo discricionário das Forças Armadas a decisão de

\footnotetext{
${ }^{62}$ SOUZA, Taiguara Libano Soares. Constituição, Segurança Pública e Estado de Exceção Permanente: A Biopolítica dos Autos de Resistência. 2010. 217 p. Dissertação de Mestrado Departamento de Direitoda Pontifícia Universidade Católica do Rio de Janeiro, Rio de Janeiro, p. 85.

${ }^{63}$ ZAVERUCHA, Jorge. Relações Civil-militares: o legado autoritário da Constituição brasileira de 1988. In TELLES, Edson e SAFATLE, Vladimir (Orgs). O que resta da ditadura: a exceção brasileira. Vol. 1. São Paulo: Boitempo, 2009, p. 45.

${ }^{64}$ Caput do Art. 142 da Constituição Federal: As Forças Armadas, constituídas pela Marinha, pelo Exército e pela Aeronáutica, são instituições nacionais permanentes e regulares, organizadas com base na hierarquia e na disciplina, sob a autoridade suprema do Presidente da República, e destinam-se à defesa da Pátria, à garantia dos poderes constitucionais e, por iniciativa de qualquer destes, da lei e da ordem.
} 
quando há ou não violação da lei e da ordem. Ou seja, concede a elas um poder importante no que se refere à política de segurança pública.

Ademais, este dispositivo permite a interpretação de que também fora conferido às Forças Armadas a função de guardiãs da Carta política de $1988^{65}$, o que é temeroso, pois abre precedentes para possíveis rupturas com a legalidade, ou seja, possibilita que as Forças Armadas possam instaurar o Estado de exceção se assim julgarem necessário ${ }^{66}$.

Vale salientar que a expressão "lei e ordem" carrega um simbolismo significativo no que diz respeito às políticas de segurança pública. No final do século XX, houve um movimento norte-americano (importado pelo Brasil em seguida) que levou esse nome e que, posteriormente, deu ensejo à política de "tolerância zero". Segundo essa política, a solução para todos os males da sociedade contemporânea estaria no direito penal e, portanto, todos os bens deveriam ser por ele protegidos, passando-se, desse modo, a criminalizar uma série de condutas e priorizar a punição em detrimento das demais políticas sociais. Havendo, por conseguinte, a substituição do Estado social para o Estado penal. João Ricardo Dornelles ao tratar do tema, enfatiza:

o mito do Estado Mínimo é sublinhado, debilitando o Estado Social e glorificando o 'Estado Penal'. É a constituição de um novo sentido comum penal que aponta para a criminalização da miséria como um mecanismo perverso de controle social para, através deste caminho, conseguir regular o trabalho assalariado precário em sociedades capitalistas neoliberais ${ }^{67}$.

Há que se considerar que essa política de combate ao crime resulta no aumento da impunidade, pois quanto mais condutas infratoras existirem, mais improvável que o Estado consiga puni-las na sua totalidade.

\footnotetext{
${ }^{65}$ SOUZA, Taiguara Libano Soares. Constituição, Segurança Pública e Estado de Exceção Permanente: A Biopolítica dos Autos de Resistência. 2010. 217 p. Dissertação de Mestrado Departamento de Direitoda Pontifícia Universidade Católica do Rio de Janeiro, Rio de Janeiro, p. 88.

${ }^{66}$ Ibid, p. 87.

${ }^{67}$ DORNELLES, João Ricardo W. Conflito e segurança- Entre pombos e falcões. Rio de Janeiro: Lumen Juris, 2003, p. 54.
} 
O caráter autoritário, anteriormente abordado, também está presente no artigo 144, inciso V, $\S 6^{068}$ da Constituição Federal, tendo em vista que ele manteve as Polícias Militares como reservas do Exército, algo comum na vigência de regimes autoritários. No entanto, no que concerne à democracia, isso somente seria cabível em períodos de guerra, pois em tempos de paz, o Exército é quem se torna força de reserva das Polícias, a fim de auxiliá-las no controle de "distúrbios sociais" 6970.

Sendo assim, a democracia traça uma linha que separa as funções da Polícia das funções das Forças Armadas. Entretanto, a maneira com que a Constituição dispõe sobre a organização das instituições policiais acentua a militarização das mesmas, acarretando, desse modo, que elas defendam mais o Estado do que o cidadão, priorizando o primeiro em detrimento do segundo. Ou seja, os bens do Estado acabam tornando-se mais valiosos do que a vida e os bens dos cidadãos.

Constata-se, portanto, que há um equívoco na atuação da Polícia Militar, visto que cabe às Forças Armadas a defesa do Estado, enquanto as polícias têm a incumbência de proteger a comunidade, garantindo a paz social, preservando a incolumidade das pessoas e do patrimônio, conforme expresso na própria Carta Magna e somente em casos excepcionais deverá atuar na defesa do Estado em conjunto com as Forças Armadas.

Isto posto, o ideal seria que houvesse a desmilitarização da Polícia Militar, resultando em uma polícia que priorize as demandas da sociedade e

\footnotetext{
${ }^{68}$ Constituição Federal - Art. 144. A segurança pública, dever do Estado, direito e responsabilidade de todos, é exercida para a preservação da ordem pública e da incolumidade das pessoas e do patrimônio, através dos seguintes órgãos: $\mathrm{V}$ - polícias militares e corpos de bombeiros militares; $\S 6^{\circ}$ As polícias militares e corpos de bombeiros militares, forças auxiliares e reserva do Exército, subordinam-se, juntamente com as polícias civis, aos Governadores dos Estados, do Distrito Federal e dos Territórios.

${ }^{69}$ SOUZA, Taiguara Libano Soares. Constituição, Segurança Pública e Estado de Exceção Permanente: A Biopolítica dos Autos de Resistência. 2010. 217 p. Dissertação de Mestrado Departamento de Direitoda Pontifícia Universidade Católica do Rio de Janeiro, Rio de Janeiro, p. 88.

${ }^{70}$ Foi o que ocorreu em abril de 2014 quando o Exército ocupou o Complexo da Maré com a finalidade de "pacificá-la", por exemplo. <http://oglobo.globo.com/rio/pacificacao-forcasarmadas-ocupamcomplexo-da-mare-12101190>. Acesso em 20.05.2015.

Vale ressaltar que o Exército já atuou desse modo em outros momentos.
} 
não as do Estado; que veja o cidadão como detentor de direitos e não como um inimigo a ser combatido, como vê, atualmente, um segmento específico da população, conforme será abordado a seguir. 


\section{Autos de Resistência: o extermínio dos invisíveis}

"São tantas e tantas mortes na favela que a gente mistura nomes e idades, como se cada um não fosse uma pessoa, não tivesse uma história, um time de futebol, uma escola de samba, um vício, um prato preferido, um jeito próprio de rir e de ficar irritado, um apelido, um medo qualquer. E não têm, pro Estado não têm.

São só pobres, favelados, tratados como cidadãos de segunda categoria a cada dia em que estiveram vivos. Tratados como insetos no momento em que são assassinados. Alguns pela polícia, outros pelos tiros disparados no meio do conflito de combate às drogas fantasiado de "politica de segurança". Todos pelo Estado.

Morrem não porque a polícia é mal preparada, ela é preparada pra fazer o que faz todos os dias: entrar na favela pra matar. Todos os dias. Todos, saindo ou não nos jornais. Um traficante, um suspeito, uma criança parada, uma senhora saindo de casa, um motoboy, um adolescente brincando de correr. Cada um com uma história, um time de futebol, uma escola de samba, um vício, um prato preferido, um jeito próprio de rir e de ficar irritado, um apelido, um medo qualquer. Que o Estado transforma em insetos, pisa, esmaga e depois solta uma nota por meio da assessoria de imprensa lamentando o acidente. Rio: 450 anos."

(Manuela Trindade Oiticica - Publicação realizada no perfil do Facebook da autora, em 03.04.2015)

Um dos grandes desafios do Estado brasileiro tem sido adotar uma política de segurança pública que combata a criminalidade e garanta a paz social e que, ao mesmo tempo, respeite integralmente os direitos e garantias fundamentais dispostos na Constituição Federal e nos tratados do quais o Brasil é signatário.

É com certa regularidade que notícias acerca da violência estatal chegam às páginas dos jornais, logo, é evidente que a frequência com que elas são perpetradas é ainda maior. O Estado costuma justificar suas ações violentas alegando estar combatendo o crime e que esta seria a única maneira de fazê-lo. A sociedade, de modo geral, costuma se calar quanto a isso. Contudo, verifica-se que essa atuação, além de ser reprovável em virtude das violações aos direitos humanos e civis, não têm dado bons resultados, pois a criminalidade ao invés de diminuir tem sido estimulada pelo uso arbitrário da força letal do Estado.

A política de segurança pública extremamente repressiva tem resultado no extermínio de um segmento específico da população: as 
classes e grupos sociais oprimidos, os excluídos, os invisíveis sociais. Essa prática histórica do uso da violência não sofreu qualquer modificação depois da promulgação da Constituição de 1988; ela é a mesma desde os tempos da colonização brasileira, quando índios e negros eram dizimados, permaneceu após a criação das forças policias brasileiras, há mais de 200 anos.

No que diz respeito ao estado do Rio de Janeiro, os homicídios praticados pelos agentes estatais - normalmente policiais Militares, uma vez que são eles os responsáveis pelo policiamento ostensivo - são registrados, quase que em sua totalidade, como "homicídios provenientes de autos de resistências" $"$. Os autores dos disparos que resultam na morte de um ou mais civis alegam, na maioria dos casos, ter agido diante de uma ou mais causas de exclusão de ilicitude: estado de necessidade, legítima defesa, estrito cumprimento do dever legal e/ou exercício regular do direito.

Embora fiquem caracterizados os "autos de resistência" em determinados episódios, como, por exemplo, quando ocorrem confrontos entre forças policiais e grupos armados, que tornam o uso da força policial legítima, é sabido, que em outras circunstâncias onde são registrados desse modo, os "autos de resistência" não estão configurados, como, por exemplo, quando os agentes policiais fazem uso excessivo da força letal, o que ocorre na maioria dos casos, tendo em vista o padrão de permanente combate empreendido nas políticas de segurança ${ }^{72}$.

\footnotetext{
${ }^{71}$ Todas as vezes que os "autos de resistência" forem citados neste trabalho estarão entre aspas, tendo em vista que na imensa maioria dos casos em que a polícia faz uso dessa classificação, o faz de modo equivocado. Utiliza-se desse instituto a fim de legitimar a política de extermínio do Estado, frequentemente colocada em praticada pelos policiais quando estes puxam o gatilho contra classes e grupos sociais oprimidos, excluídos e invisíveis da sociedade. Ou seja, as aspas são o recurso empregado para desconstruir o modo com que o conceito é apresentado e aplicado pelas autoridades policiais, destacando que apesar dos casos serem assim classificados, não são casos, necessariamente, contemplados pelo instituto.

${ }^{72}$ SOUZA, Taiguara Libano Soares. Constituição, Segurança Pública e Estado de Exceção Permanente: A Biopolítica dos Autos de Resistência. 2010. 217 p. Dissertação de Mestrado Departamento de Direitoda Pontifícia Universidade Católica do Rio de Janeiro, Rio de Janeiro, p. 154.
} 
A classificação de episódios como "autos de resistência" é feita, portanto, de modo discricionário e desmedido pelos policiais, e, muitas vezes, tem como finalidade encobrir execuções sumárias. O "auto de resistência" tornou-se uma ferramenta que atende à política de extermínio do Estado brasileiro. Essa prática, que deveria ser coibida pelos demais órgãos estatais e pela sociedade, não o é: esses costumam ratificar a conduta policial, como será abordado mais adiante.

Faz-se necessário esclarecer que, atualmente, o "auto de resistência" existe também em casos em que o resultado final não é a morte do indivíduo. Nessas circunstâncias, a vítima torna-se autora do fato, ré da ação penal. Ou seja, há uma incompleta inversão da situação: se morto for, será vítima; estando vivo, será réu.

A previsão legal do que hoje conhecemos como "autos resistência" no Rio de Janeiro, "resistência seguida de morte" em São Paulo, "resistência em situação de confronto" ou simplesmente "resistência" nos demais estados da Federação, remonta à época da ditadura militar, um dos períodos mais sombrios da história do Brasil. É uma época marcada por medidas excepcionais, em que houve a legalização da pena de morte, da prisão perpétua, além da prática clandestina da tortura, do extermínio e da ocultação de cadáver ${ }^{73}$. No entanto, vale salientar que a conduta policial, que leva à lavratura do "auto", existe há mais tempo, é uma prática corrente adotada no Brasil desde os tempos de Colônia.

O "auto de resistência" foi oficialmente criado em 02 de outubro de 1969, pela Superintendência da Polícia do então Estado da Guanabara, através da Ordem de Serviço "N”, no 803 e publicada no Boletim de Serviço em 21 de novembro de $1969^{74}$. Dispunha sobre a dispensa da prisão em

\footnotetext{
${ }^{73}$ VERANI, Sérgio. Assassinatos em nome da lei - Uma prática ideológica do Direito Penal. Rio de Janeiro: Aldebarã, 1996, p. 46/47.

${ }^{74}$ Ibid, p. 33.
} 
flagrante ou do inquérito nas circunstâncias previstas no artigo 292 do Código de Processo Penal ${ }^{75}$.

O seu conteúdo foi ampliado através da Portaria “E”, no 0030 de 06 de dezembro de 1974, do Secretário de Segurança Pública e publicada no Boletim de Serviço três dias depois.

Ao analisá-la é possível constatar que não há qualquer preocupação em elucidar se houve realmente resistência por parte do opositor e se a conduta policial foi correta e sim, que todos os procedimentos adotados têm como finalidade esclarecer as condutas penais consumadas ou tentadas pelo opositor.

Segue o texto da Portaria "E", no 0030:

(...) Considerando que somente o inquérito regular poderá fornecer à Justiça os elementos de convicção de excludente criminal em favor dos policiais que agiram no estrito cumprimento do dever e em legítima defesa; considerando, finalmente, que a diversidade de providências adotadas por autoridades policiais desta Secretaria, quando diante de fatos concretos da espécie, acarreta, por vezes, retardamentos prejudiciais à Justiça e ao serviço policial, resolve:

1. A presente portaria objetiva uniformizar o procedimento das autoridades policiais da Secretaria de Segurança Pública nos eventos decorrentes de missões de segurança em que o policial, no estrito cumprimento do dever e em legítima defesa, própria ou de terceiro, tenha sido compelido ao emprego dos meios de força necessários, face à efetiva resistência oferecida por quem se opôs à execução do ato legal.

2. Ocorrendo a morte do opositor, a autoridade determinará imediata instauração de inquérito, para a perfeita elucidação do fato, que compreende:

a. as razões de ordem legal da diligência;

b. as figuras penais consumadas ou tentadas pelo opositor durante a resistência;

c. a apuração da legitimidade do procedimento do policial.

2.1. O inquérito poderá ser instruído com o auto de resistência, lavrado nos termos do art. 292, do Código de Processo Penal, e, necessariamente, com o auto de exame cadavérico e o atestado de óbito do opositor, para permitir ao Juízo apreciar e julgar extinta a punibilidade dos delitos cometidos ao enfrentar o policial.

\footnotetext{
${ }^{75}$ Código de Processo Penal - Art. 292: Se houver, ainda que por parte de terceiros, resistência à prisão em flagrante ou à determinada por autoridade competente, o executor e as pessoas que o auxiliarem poderão usar dos meios necessários para defender-se ou para vencer a resistência, do que tudo se lavrará auto subscrito também por duas testemunhas.
} 
2.2. O inquérito deverá ficar concluído e relatado no prazo máximo de 30 dias, cabendo à autoridade promover a remessa dos autos ao Juízo competente para processar e julgar os crimes praticados pelo opositor.

3. Quando, apesar da resistência, o opositor houver sido dominado e preso ou logrou evadir-se, a autoridade policial adotará as medidas adequadas estabelecidas no Código de Processo Penal.

3.1. A apuração, no caso deste item, também deverá abranger a legitimidade da atuação do policial.

4. Na hipótese de serem vários os opositores, em coautoria, ocorrendo a morte de algum, sendo presos vários outros e se evadindo os demais, a autoridade deverá:

a. ordenar a lavratura do auto de prisão em flagrante para os que foram dominados e presos;

b. promover a instrução dos autos na forma do item 2 desta portaria;

c. determinar diligências para a perfeita identificação dos que se evadiram.

4.1. Na impossibilidade de concluir, no prazo legal, as diligências aludidas na alínea $c$ deste item, a autoridade deverá sugerir ao Juízo competente a separação processual, com fulcro no art. 80, do Código de Processo Penal, a fim de não retardar o início da ação penal contra os já identificados ${ }^{76}$.

É importante destacar a Portaria para pensar/compreender seu conteúdo, dado que mera interpretação não faria jus à mesma. Seu texto é peculiar, pois desde o princípio já expressa à convicção de que a ação policial foi uma conduta legal. Logo, constata-se que a Portaria foi criada em benefício dos policiais e em detrimento das vítimas, que não tem seus casos elucidados, tendo suas vidas resumidas às folhas policiais e "para sempre" lembradas como meliantes, traficantes, bandidos, delinquentes, mesmo quando não possuem qualquer anotação em suas folhas de antecedentes criminais (FAC). A memória das vítimas é vilipendiada em prol da impunidade dos agentes policiais.

Os "autos de resistência" legitimam a pena de morte, a prática de extermínio perpetrada pelo Estado, as vítimas vivem na condição de homo sacer $^{77}$, tendo suas vidas reduzidas a meras vidas nuas matáveis. Os agentes policiais e os governos, estes últimos que operacionalizam tais práticas

\footnotetext{
${ }^{76}$ VERANI, Sérgio. Assassinatos em nome da lei - Uma prática ideológica do Direito Penal. Rio de Janeiro: Aldebarã, 1996, p. 35/36.

${ }_{77}$ AGAMBEN, Giorgio. Homo Sacer: o poder soberano e a vida nua. Belo Horizonte: Editora UFMG, 2002.
} 
através das políticas de segurança pública, permanecem impunes, não são responsabilizados pelos seus atos.

Contudo, há que se considerar que esse processo é seletivo, apenas "funciona" quando direcionado à população excluída socialmente, aos invisíveis. Pois se a vítima de um disparo efetuado pela PM for de classe média, por exemplo, o resultado divergirá. Nesse caso não há o que se falar em "autos de resistência", dificilmente falar-se-á de impunidade para com o agente que cometeu o disparo, improvável, também, que o caso seja arquivado sem qualquer investigação acerca dos fatos. Visto que a vida do sujeito de classe média é considerada mais valiosa do que a vida de um morador da favela, ele não vive sua vida na condição de homo sacer, assim como esse último. Logo, sua vida é protegida, é estimada.

Infelizmente em algum momento da história, alguém se achou no direito de determinar quais vidas são inferiores as demais e, lamentavelmente, essa percepção equivocada não mudou, continua sendo perpetrada cotidianamente nas favelas, nas periferias, nos quilombos, em todos os territórios que, de algum modo, há uma população que não se inseriu na ordem econômica vigente. Nessa perspectiva Nilo Batista exprime:

A tendência genocida responde a uma organização social internamente excludente e discriminatória, e externamente imperialista, que converte o estado em agressivo servidor aparelhado dos interesses de uma classe. Tal estado, por ação, negligência ou omissão extermina ou tolera que exterminem, direta ou indiretamente, as "classes perigosas", os inúteis, ou incômodos marginalizados ${ }^{78}$.

O nexo entre violência e direito é acionado pelo estado de exceção. E, o "auto de resistência" tem um papel importante nesse contexto, devido ao seu caráter ambivalente e antagônico, já que para garantir a segurança, a incolumidade física e a vida de um conjunto da população, ele assegura a matabilidade de certa categoria de indivíduos, naturalizando a morte de

\footnotetext{
${ }^{78}$ BATISTA, Nilo. Punidos e mal pagos: violência, justiça, segurança pública e direitos humanos no Brasil de hoje. Rio de Janeiro: Revan, 1990, p. 49.
} 
sujeitos considerados não tutelados pela ordem jurídica, os inimigos da sociedade $^{79}$ ou, como Nilo Batista definiu, as "classes perigosas".

\subsection{Quando o procedimento vira processo}

A fim de que se compreenda melhor o que são os "autos de resistência" e como eles funcionam na prática é necessário conhecer o passo-a-passo, cada etapa do procedimento, que fará com que eles tornemse ou não processos judiciais. Porém, vale salientar que a grande maioria dos Inquéritos Policiais classificados como "autos de resistência" não chegam a essa fase, distintamente do que ocorre com os casos de homicídio que não são cometidos por policiais que, geralmente, chegam à fase processual.

Ademais, é importante analisar o comportamento e os discursos de todos os atores judiciários (policiais, delegados, promotores, juízes) durante esse processo, pois a postura de cada um deles é determinante para a propositura ou não da ação penal, para que o caso seja ou não esclarecido.

\subsubsection{Registro de Ocorrência}

Quando ocorre um homicídio praticado por policiais, sejam civis ou militares (mais frequente este último), e eles alegam terem agido em legítima defesa ou em conformidade com qualquer uma das causas excludentes de ilicitude previstas no artigo 23 do Código Penal ${ }^{80}$, no Registro de Ocorrência (RO) que será lavrado na delegacia, a morte receberá a classificação "homicídio proveniente de autos de resistência" ou "homicídio decorrente de intervenção policial". Trata-se de uma

\footnotetext{
${ }^{79}$ SOUZA, Taiguara Libano Soares. Constituição, Segurança Pública e Estado de Exceção Permanente: A Biopolítica dos Autos de Resistência. 2010. 217 p. Dissertação de Mestrado Departamento de Direitoda Pontifícia Universidade Católica do Rio de Janeiro, Rio de Janeiro, p. 163.

${ }^{80}$ Código Penal - Art. 23: Não há crime quando o agente pratica o fato: I - em estado de necessidade; II - em legítima defesa; III - em estrito cumprimento de dever legal ou no exercício regular de direito.

Parágrafo único - $\mathrm{O}$ agente, em qualquer das hipóteses deste artigo, responderá pelo excesso doloso ou culposo.
} 
classificação administrativa, feita por policiais civis, a fim de orientar o trabalho investigativo ${ }^{81}$, bem como possibilitar que estes casos sejam contabilizados e divulgados através do Instituto de Segurança Pública do Estado do Rio ${ }^{82}$.

O "auto de resistência" advém ${ }^{83}$ do art. 292 do CPP, que define as circunstâncias e o procedimento que será adotado caso venha a ocorrer um "auto". Mas, vale dizer, que o crime de resistência está previsto no art. $329^{84}$ do Código Penal.

Ao lavrar o auto a tipificação penal aplicada no Registro de Ocorrência será de homicídio, prevista no art. $121^{85}$ do Código Penal, combinada com o art. 23 do mesmo, que prevê as causas de exclusão de ilicitude. A classificação "auto de resistência" ou "homicídio decorrente de intervenção policial" é apenas administrativa, não seguirá caso o Inquérito Policial chegue à fase processual.

É comum que as notificações das mortes à delegacia sejam realizadas pelos próprios agentes policiais, autores do homicídio e, que as duas testemunhas que devem acompanha-los sejam também policiais envolvidos no caso noticiado. Isso ocorre, pois não é comum que outras testemunhas oculares compareçam à delegacia, seja por falta de interesse ou

\footnotetext{
${ }^{81}$ MISSE, Michel; GRILLO, Carolina Christoph; TEIXEIRA, César Pinheiro; NERI, Natasha Elbas. Quando a polícia mata: homicídios por "autos de resistência" no Rio de Janeiro (20012011). Rio de Janeiro: NECVU; Booklink, 2013, p. 47.

${ }^{82}$ Os balanços mensais das incidências criminais ocorridas no estado do Rio de Janeiro são publicados no site, mas vale dizer que são divididos conforme as Áreas Integradas de Segurança Pública - AISP. <http://www.isp.rj.gov.br/>. Acesso em 23/05.2015.

O contorno geográfico de cada AISP foi estabelecido a partir da área de atuação de um batalhão de Polícia Militar e as circunscrições das delegacias de Polícia Civil contidas na área de cada batalhão. A atual divisão territorial do Estado do Rio de Janeiro, segundo o critério de Áreas Integradas de Segurança Pública, contempla um total de 39 AISP, conforme a Resolução SESEG $\mathrm{n}^{\mathrm{o}}$. 478 de $11 / 05 / 2011$.

${ }^{83}$ Há uma controvérsia se este artigo autoriza o procedimento administrativo do 'auto de resistência', diferenciando-o claramente de uma autuação normal de homicídio. SOUZA, Taiguara Libano Soares. Constituição, Segurança Pública e Estado de Exceção Permanente: A Biopolítica dos Autos de Resistência. 2010. 217 p. Dissertação de Mestrado - Departamento de Direitoda Pontifícia Universidade Católica do Rio de Janeiro, Rio de Janeiro, p. 158.

${ }^{84}$ Caput do Art. 329 do Código Penal: Opor-se à execução de ato legal, mediante violência ou ameaça a funcionário competente para executá-lo ou a quem lhe esteja prestando auxílio.

${ }^{85}$ Caput do Art. 121 do Código Penal: Matar alguém.
} 
por medo de represálias ${ }^{86}$. Logo, a primeira versão obtida pela Polícia Civil é a prestada pelos agentes policiais e, normalmente, é a versão que será considerada como oficial, posteriormente.

Importa salientar, que nem sempre os policiais se utilizam da classificação "auto de resistência". Em determinadas circunstâncias, quando a vítima é uma criança ou pessoa idosa e, o argumento de que o disparo que resultou no homicídio foi efetuado em confronto torna-se pouco crível, eles servem-se de outras "tipificações", como, por exemplo, bala perdida".

Em alguns casos de "auto de resistência” são incluídos nos ROs os crimes imputados ao morto. Quando isso ocorre ele aparecerá tanto como "vítima" (do homicídio proveniente de autos de resistência), quanto como "autor" (dos crimes que tenha cometido, se houver, bem como da resistência ou tentativa de homicídio contra os policiais), sendo assim os policiais, nesses casos específicos, aparecem como "vítimas". Nesse sentido, Michel Misse enfatiza:

Tal formalização da culpabilidade das pessoas mortas em "autos de resistência" constitui o primeiro passo do processo - quase que sistêmico - de incriminação das mesmas, iniciando a construção da narrativa que justifica o seu óbito ${ }^{88}$.

Há operações policiais que resultam na prisão de um suspeito e na morte de outro. Nesses casos, caberá ao delegado decidir se irá efetuar um único registro, denominado "Flagrante" ou se irá desmembrar a ocorrência em dois registros, um para apurar o "homicídio proveniente de auto de resistência" e o outro para o flagrante do indivíduo que foi preso por suposta tentativa de homicídio contra os policiais.

\footnotetext{
${ }^{86}$ MISSE, Michel; GRILLO, Carolina Christoph; TEIXEIRA, César Pinheiro; NERI, Natasha Elbas. Quando a polícia mata: homicídios por "autos de resistência" no Rio de Janeiro (20012011). Rio de Janeiro: NECVU; Booklink, 2013, p. 51.

${ }^{87}$ SOUZA, Taiguara Libano Soares. Constituição, Segurança Pública e Estado de Exceção Permanente: A Biopolítica dos Autos de Resistência. 2010. 217 p. Dissertação de Mestrado Departamento de Direitoda Pontifícia Universidade Católica do Rio de Janeiro, Rio de Janeiro, p. 158.

${ }^{88}$ MISSE, Michel; GRILLO, Carolina Christoph; TEIXEIRA, César Pinheiro; NERI, Natasha Elbas. Quando a polícia mata: homicídios por "autos de resistência" no Rio de Janeiro (20012011). Rio de Janeiro: NECVU; Booklink, 2013, p. 51.
} 
No mesmo momento em que se efetua o RO, há também a coleta dos depoimentos dos policiais, denominadas Termos de Declaração. É comum que tais termos não variem muito de conteúdo, sendo sempre semelhantes nas ocorrências de "autos de resistência", compondo uma espécie de narrativa-padrão ${ }^{89}$, onde apenas muda-se o nome dos autores das declarações e suas participações específicas. Logo, é possível constatar uma espécie de consenso sobre a conduta policial e a maneira com que, estruturalmente, a polícia administra os conflitos e as mortes que deles resultam.

De acordo com Michel Misse, na maioria dos casos por ele analisados, os policias em seus Termos de Declarações, sempre alegam, nas ocorrências dos "autos de resistência", que estavam em patrulha ou em operação, próximo ou em localidades dominadas por traficantes armados. E que em algum momento foram alvejados e, portanto, revidaram a "injusta agressão", e que assim que os disparos cessaram, encontraram um ou mais "elementos" baleados, geralmente com armas e drogas por perto, sendo lhes prestado socorro imediato, conduzindo-os ao hospital. Nesses casos, frequentemente, é relatado que o sujeito baleado morreu no caminho do hospital e, os Boletins de Atendimento Médicos posteriormente atestam que quando a vítima deu entrada no hospital ela já havia falecido ${ }^{90}$.

Sobre isso vale salientar duas coisas. A primeira refere-se ao jeito com que as vítimas são descritas, sempre como "bandidos", "meliantes", "elementos", com o intuito de desqualificá-las, como se suas vidas valessem menos devido às supostas condutas por ela praticadas, que, ressalta-se, nem sempre ficam comprovadas. A segunda, que esses préstimos de socorro ocorrem, muitas vezes, quando a vítima já está morta, logo, percebe-se que o intuito real não é socorrê-la e sim mudar a cena do crime, impossibilitando futuras perícias no local ${ }^{91}$. Inclusive, um juiz que

\footnotetext{
${ }^{89}$ Ibid, p. 52.

${ }^{90}$ Ibid, p. 53.

${ }^{91}$ Ibid, p. 57.
} 
trabalha há oito anos no Tribunal do Júri relatou que nunca havia visto um caso narrado como sendo de morte em confronto em que o corpo tivesse sido deixado no local para a realização da perícia local ${ }^{92}$.

Há policiais que argumentam que as mortes costumam ocorrer em áreas consideradas de "risco", devido à presença de grupos armados, não sendo possível manter o corpo no local, pois não haveria como resguardálos em segurança (o corpo e o local). Ocorre que quando os policiais são indagados sobre a chegada das vítimas já mortas no hospital, eles alegam que elas morreram no caminho. Ou seja, há uma contradição nas falas dos próprios policiais, ou a vítima morreu no local do crime ou no trajeto da ida ao hospital, ambas as coisas não podem ter acontecido.

Cabe destacar ainda, que o número de policiais mortos em serviço é extremamente inferior ao número de "homicídio proveniente de autos de resistência". Apenas para ilustrar, no Rio de Janeiro, no mês de abril do ano passado, segundo dados oficiais disponibilizados pelo ISP, houve trinta e sete (37) "homicídios decorrentes de intervenção policial", enquanto um (1) policial morreu em serviço, já em abril deste ano, houve cinquenta e nove (59) "homicídios decorrentes de intervenção policial”, enquanto morreram dois (2) policiais em serviço ${ }^{93}$. Portanto, vê-se, novamente, que há uma incongruência entre o que é relatado pelos policiais e a realidade, pois a discrepância entre os números é muito alta.

No Registro de Ocorrência há um espaço reservado para a Dinâmica do Fato e compete a Polícia Civil preenchê-lo, por tratar-se da primeira versão oficial que será dada ao caso. Os policiais civis têm por hábito formular a versão oficial com base dos Termos de Declaração, inclusive, a Dinâmica costuma ser extremamente semelhante a este último, muda-se somente a maneira com que as informações estão dispostas. Ou seja, esta

\footnotetext{
92 Ibid, p. 82.

93 Disponível em: <http://arquivos.proderj.rj.gov.br/isp_imagens/Uploads/ResumoAbr15.pdf>. Acesso em 23/05.2015. Para maiores informações consultar o site do ISP. $<$ http://www.isp.rj.gov.br/>. Acesso em 23.05.2015.
} 
tornou-se mais uma ferramenta utilizada para legitimar a conduta policial, visto que é através dela que oficializa-se a narrativa de legítima defesa ${ }^{94}$.

Concomitante ao RO é formalizado o encaminhamento do corpo da vítima ao Instituto Médico Legal (IML) e solicita-se que seja realizado o “Auto de Exame Cadavérico95". Quanto aos bens apreendidos na operação policial, como armas e drogas, bem como as armas utilizadas pelos policiais, são todas relacionadas no item chamado Bens Envolvidos. Para cada um deles é realizado um Auto de Apreensão e encaminhado ao Instituto de Criminalística Carlos Éboli (ICCE) acompanhados de uma Requisição de Exame Pericial Direto.

Contudo, vale ressaltar, que a apreensão das armas dos policiais envolvidos ocorre de maneira virtual, isto é, a apreensão é seguida de um Auto Depósito, em que os próprios são denominados responsáveis da mesma e comprometem-se a levá-las para serem periciadas ${ }^{96}$.

\subsubsection{Inquérito Policial}

Obrigatoriamente, na ocorrência de todo e qualquer homicídio, é necessário que seja instaurado o Inquérito Policial, logo, o mesmo ocorre nos casos de "autos de resistência".

O IP é instaurado pelo delegado - seja ele titular, assistente ou adjunto - através de um despacho e de uma portaria, na qual resume a ocorrência conforme as informações contidas no RO e, enumera as diligências que deverão ser efetuadas a fim de apurar os fatos. No Inquérito constam todos os documentos e informações reunidos no Registro de Ocorrência.

\footnotetext{
${ }^{94}$ MISSE, Michel; GRILLO, Carolina Christoph; TEIXEIRA, César Pinheiro; NERI, Natasha Elbas. Quando a polícia mata: homicídios por "autos de resistência" no Rio de Janeiro (20012011). Rio de Janeiro: NECVU; Booklink, 2013, p. 56.

${ }^{95} \mathrm{O}$ auto de exame cadavérico é uma espécie de autópsia, realizada para confirmar a morte e atestar o motivo desta.

96 MISSE, Michel; GRILLO, Carolina Christoph; TEIXEIRA, César Pinheiro; NERI, Natasha Elbas. Quando a polícia mata: homicídios por "autos de resistência" no Rio de Janeiro (20012011). Rio de Janeiro: NECVU; Booklink, 2013, p. 58.
} 
Importa frisar duas peculiaridades do Inquérito Policial de "autos de resistência": na capa dos inquéritos menciona-se que, além de tratarem-se de homicídios, são provenientes de "autos de resistência", logo, parte-se, desde o início, da presunção de legalidade dessas mortes ${ }^{97}$. E, na portaria os delegados costumam narrar os fatos como praticados em legítima defesa, ressalta-se que isso ocorre antes mesmo das investigações terem sido iniciadas. Ou seja, desde o princípio os delegados tomam como verdade o que fora narrado pelos policiais no RO, prevalecendo à fé pública dos mesmos. É conduta atípica contestar os fatos narrados pelos agentes ${ }^{98}$.

Cabe salientar que há entre os policiais, tanto civis como militares, o discurso de que bandidos "merecem morrer" e, portanto, que o uso da força letal por parte dos policiais está correta, justifica-se, pois o sujeito (vítima) já havia cometido algum crime, logo não é um cidadão contemplado por direitos.

$\mathrm{Na}$ pesquisa realizada por Misse, um dos policiais entrevistados ao falar sobre como compreende sua atividade e o que pensa dos Direitos Humanos faz a seguinte declaração:

$\mathrm{O}$ que eu não concordo é com direitos humanos para abanar vagabundo. Eu concordo com os direitos humanos que você tem que dar educação, saúde pro povo. (...) Nós trabalhamos em cima da realidade. Não tem ONG parar amparar família de policial morto, não há igualdade. Mais da metade dos policiais entendem que direitos humanos devem ser dados a que é de direito ${ }^{99}$.

Constata-se que a ideologia de extermínio "bandido bom, é bandido morto" está fortemente presente nas instituições policiais. Generosa parcelara de seus agentes defendem e acreditam que as supostas condutas criminais praticadas por um cidadão, os quais chamam de "meliante", "bandido", "criminoso", etc., fazem desses indivíduos sujeitos sem direitos,

\footnotetext{
${ }^{97}$ Ibid, p. 59.

${ }^{98}$ Ibid, p. 62.

${ }^{99}$ Ibid, p. $62 / 63$.
} 
colocando-os na condição de homo sacer $^{100}$, estudada no pensamento de Agamben.

Nesse sentido, Nilo Batista exprime:

No Brasil, não temos a pena de morte na legislação, mas ela é aplicada largamente, tolerada e estimulada por discursos que ou desqualificam o acusado ("ele é bandido"), liberando-o à sanha dos esquadrões da morte a soldo de grupos policiais bem caracterizados, ou exercem diretamente a apologia do extermínio ("bandido bom, é bandido morto") ${ }^{101}$.

Nos "autos de resistência", diferente dos demais casos de homicídio, sabe-se a autoria do crime, contudo não há indiciamento ou a prisão em flagrante do autor, pois desde o princípio defende-se que este agiu amparado por uma ou mais causas excludentes de ilicitude, logo, sustentase que agiu legalmente. Desse modo, evita-se possíveis sanções disciplinares.

Ademais, evitando o indiciamento, os policias resguardam-se de terem suas carreiras estagnadas, tendo em vista que o indiciamento os impediria de obterem possíveis promoções durante o andamento do inquérito, que costuma ser demorado, levando em média mais de cinco anos para ser concluído. Além disso, essa infração penal constaria em suas Folhas de Antecedentes Criminais ${ }^{102}$ (FACs).

É necessário lembrar que há casos em que uma mesma operação policial resulta em um "auto de resistência" e em um Flagrante, ou seja, na morte e na prisão de alguém. Nesses casos, o preso é indiciado por tentativa de homicídio contra os policiais, através do Auto de Qualificação Direto e, no mesmo RO consta o "auto de resistência" e, normalmente todos os documentos contidos no "auto de resistência" estão presentes no Flagrante.

\footnotetext{
100 AGAMBEN, Giorgio. Homo Sacer: o poder soberano e a vida nua. Belo Horizonte: Editora UFMG, 2002.

101 BATISTA, Nilo. Punidos e mal pagos: violência, justiça, segurança pública e direitos humanos no Brasil de hoje. Rio de Janeiro: Revan, 1990, p. 103.

${ }^{102}$ MISSE, Michel; GRILLO, Carolina Christoph; TEIXEIRA, César Pinheiro; NERI, Natasha Elbas. Quando a polícia mata: homicídios por "autos de resistência" no Rio de Janeiro (20012011). Rio de Janeiro: NECVU; Booklink, 2013, p. 63.
} 
O prazo é um diferencial entre um procedimento e outro, enquanto o Flagrante tem permanência de 10 dias na delegacia, o IP tem de 30 dias, ademais o Flagrante é apreciado por um promotor da Central de Inquéritos, mas de uma Vara Penal, enquanto o IP de um homicídio é apreciado pela Vara do Júri.

$\mathrm{Na}$ ocorrência desses casos, regularmente, o "homicídio proveniente de auto de resistência" é arquivado. Pois, segundo o relatado por promotores da Vara do Júri ${ }^{103}$, a prisão corrobora a legitimidade da ação policial.

Enquanto isso, aquele que sobreviveu é indiciado por tentativa de homicídio contra os policiais. Ou seja, quando o sujeito não morre, ele vira réu.

Após a instauração dos Inquéritos Policiais, estes são distribuídos pelo delegado titular entre os chamados sindicantes de inquérito, um grupo restrito que trabalha somente com IPs, composto por aproximadamente seis agentes. Frequentemente um sindicante fica responsável por cuidar apenas dos inquéritos de homicídios, englobando os "autos de resistência".

No entanto, diante do grande volume de inquéritos para serem analisados/investigados e dos prazos regulamentados, os policiais e delegados selecionam os casos que devem ser priorizados, conforme sua repercussão na mídia, a gravidade do caso, a posição social da vítima e as motivações pessoais dos envolvidos. Contudo, os IPs de "autos de resistência" normalmente não estão incluídos nesse rol e, portanto, recebem menos atenção dos sindicantes. A exceção ocorre quando um "homicídio proveniente de auto de resistência" tem grande repercussão na mídia ou quando há um grande engajamento de grupos ligados à defesa de direitos humanos acompanhando o caso. Mas, a maior parcela deles é deixada de lado, pois muitos agentes consideram os casos de "autos de resistência" não investigáveis.

${ }^{103}$ Ibid, p. 64. 
Na pesquisa realizada por Misse, um policial civil adepto da pena de morte e que acredita que "bandido não é cidadão", declarou:

Geralmente, quando morre bandido em confronto com a polícia, o que a gente chama de auto de resistência, quando a polícia chega num lugar e vagabundo recebe à bala, aí não tem jeito. O policial tem que se defender. Nesses casos não há investigação. A gente simplesmente acata o que o policial diz e manda pro Ministério Público com pedido de arquivamento ${ }^{104}$.

Como a lei não mata oficialmente, ela mata extraoficialmente. $\mathrm{O}$ executor da lei acaba sendo o executor da pena ${ }^{105}$.

Diante da postura adotada por muitos policiais, constata-se que não há interesse em solucionar estes casos. Há uma crença que a conduta praticada pelo PM está correta, que uma das funções do policial é "matar bandido", e deste modo realiza-se o controle social, opera-se a manutenção de posições de poder, mantém-se o status quo. Para a maior parte desses policiais, o ideal é que os inquéritos de "autos de resistência" sejam arquivados e muitos trabalham para que isso ocorra.

O IP tem um prazo de 30 dias para ser concluído, sendo, posteriormente, encaminhado para a Central de Inquéritos do Ministério Público, para que o promotor solicite novas diligências, denuncie o caso ou solicite arquivamento. Contudo, normalmente esse prazo não é suficiente, sendo comum que os policiais responsáveis solicitem que o prazo seja estendido, inclusive, geralmente há vários pedidos nesse sentido quando tratam-se de casos de "auto de resistência", tendo, estes, sido batizados por policiais e promotores como "pingue-pongue"106. Porém, vale dizer que apesar de ficarem indo e vindo, virtual ou fisicamente, entre a delegacia e o Ministério Público, pouco é feito para investigar estes casos.

O inquérito só pode ser finalizado, isto é, ter o relatório final redigido após conter todas as peças consideradas essenciais pela autoridade policial, caso contrário estará incompleto. No que concerne aos "homicídios

\footnotetext{
${ }^{104}$ Ibid, p. 66.

105 Ibid, p. 67.

${ }^{106}$ Ibid, p. 70.
} 
provenientes de autos de resistência", geralmente contém as seguintes peças: Boletim de Atendimento Médico (BAM); Auto de Exame Cadavérico (AEC); Laudo de Exames Periciais Diretos das armas dos policiais, bem como da arma e demais bens apreendidos junto ao corpo; Folha de Antecedentes Criminais (FAC) da vítima; Termos de Declarações dos policiais e, ocasionalmente, de algum parente ou amigo da vítima ${ }^{107}$. Raramente consta a FAC do policial ou as anotações que ele, porventura, recebeu no exercício de sua função. Ou seja, o inquérito é desenvolvido com o objetivo de se investigar os mortos, e não as mortes.

Muitas são as justificativas para não haver investigações acerca dos "autos de resistência", dentre as que se destacam: envolvem, em sua maioria, pessoas de baixa renda, moradores de favela; o autor do crime é um policial, logo, gera-se uma espécie de coleguismo; alguns investigadores não desejam se indispor com o policial, autor do fato, pois trabalham na mesma área; o delegado precisa dos policiais para efetuar diligências, portanto precisa manter uma boa relação com os PMs e, por fim, muitos compartilham da ideia de combate ao inimigo, sendo o "bandido" a figura do inimigo.

Outros fatores prejudiciais às investigações são o excesso de burocracia, o tempo que os laudos levam para ficarem prontos (isso quando todas as perícias são realizadas, pois em muitos casos elas não são), e a precária comunicação entre as delegacias e os institutos de polícia técnica. Apenas para ilustrar essa deficiência, há casos em que os laudos são enviados para a delegacia errada, ou são trocados, erros que podem ser identificados prontamente ou que levarão anos para serem descobertos.

Cabe pontuar, que normalmente nos casos de "autos de resistência" não são efetuadas diligências externas, bem como raramente outras testemunhas se apresentam para depor, há casos em que os próprios

${ }^{107}$ Ibid, p. 69. 
familiares não comparecem na delegacia ou comparecem, mas não prestam nenhum esclarecimento de modo oficial.

Há, ainda, casos em que familiares e amigos da vítima entram em contato diretamente com os promotores da Central de Inquéritos para prestarem depoimentos, devido ao medo que sentem que os policiais, envolvidos no homicídio, saibam que depuseram. Quando isso ocorre, geralmente os depoimentos são tomados em sigilo e não anexados ao inquérito, para que ninguém tenha acesso ao conteúdo na delegacia ${ }^{108}$.

Nos raros casos em que há outras testemunhas, além dos policiais, as perguntas a elas direcionadas costumam centrar-se na caracterização moral da vítima, como, por exemplo, quais eram suas ocupações (estudava, trabalhava), se tinha algum envolvimento com drogas e com o tráfico e qual era o seu comportamento perante as demais pessoas. Salienta-se que as perguntas realizadas nunca constam no RO. Se, porventura, o depoente afirmar ou deixar subentendido uma possível conduta criminosa, essa declaração é utilizada para endossar a argumentação oficial de que houve legítima defesa na atuação do policial.

Quanto às peças técnicas, cabe dizer que as mesmas, habitualmente, são muito precárias, os laudos costumam ser vagos, não auxiliando na elucidação dos casos. No que concerne à arma apreendida da vítima, por exemplo, há, inclusive, uma resposta padrão: "Informam os peritos que não há meios seguros para a determinação de vestígios de disparo na arma periciada, face aos novos tipos de pólvora e lubrificantes utilizados modernamente ${ }^{109,}$. Ademais, além dessa limitação técnica, raramente são realizados exames para buscar vestígios de pólvora nas mãos da vítima e, quando estes são feitos, ainda existe a possibilidade de darem um falso negativo, segundo o relatado por promotores.

\footnotetext{
${ }^{108}$ Ibid, p. 73

${ }^{109}$ Ibid, p. 80.
} 
Já no que se refere às armas dos policiais, como pontuado anteriormente, estas são apreendidas virtualmente, sendo os próprios os depositários das mesmas, o que contribui para a demora das armas serem periciadas, pois há demora na sua entrega e, em casos extremos, elas não chegam a ser entregues para o ICCE, onde as perícias são realizadas.

Vale esclarecer, também, que são raros os casos em que ocorre o confronto balístico, tendo em vista a dificuldade de serem obtidos os projéteis no cadáver ou na cena do crime. Haja vista que a principal arma utilizada pelos policiais, o fuzil 762 , possuí tiros transfixantes ${ }^{110}$, ou seja, os projéteis não se alojam no corpo da vítima e, além disso, como já abordado anteriormente, é incomum que se faça perícia no local do crime, o que impede o recolhimento de projéteis que possibilitem o Exame de Confronto de Balística. Portanto, como se observa, a perícia nas armas pouco influencia na elucidação dos casos.

O laudo técnico com maior importância nos casos de "autos de resistência" são os Autos de Exame Cadavérico (AECs), pois a partir deles é possível determinar o que ocorreu com a vítima, se foi alvejada de frente ou de costas, se o tiro foi à queima roupa, caracterizando uma execução ou se foi à longa distância, bem como se há outros indícios de violência no corpo da vítima, como, por exemplo, escoriações, equimoses, hematomas e fraturas. Contudo, é importante ressaltar que, na maioria dos casos de "homicídios provenientes de autos de resistência", mesmo havendo fortes indícios de execução, o Inquérito Policial normalmente é arquivado não chegando à fase processual.

Como abordado outrora, após a instauração dos Inquéritos Policiais, estes devem ser encaminhados no prazo de 30 dias à Central de Inquéritos para serem distribuídos à Promotoria de Investigação Penal (PIP) responsável ${ }^{111}$. Isso deve ser feito, inclusive, nos casos em que o inquérito

\footnotetext{
${ }^{110}$ Ibid, p. 81.

${ }^{111}$ Os procedimentos de flagrante não vão para as Centrais de Inquérito, mas diretamente ao juiz e à vara criminal correspondente - Ibid, p. 84 (nota de rodapé).
} 
não tenha sido concluído, podendo o delegado solicitar a prorrogação do prazo para prosseguir com as investigações.

Acerca da Central de Inquérito é imprescindível pontuar que a mesma é composta por 23 Promotorias de Investigações Penais (PIPs), nas quais, cada promotor costuma ser responsável por duas delegacias da cidade do Rio de Janeiro ${ }^{112}$. Entre as atribuições conferidas aos promotores estão: a fiscalização do trabalho policial; a análise do material contido nos inquéritos e a avaliação se devem remetê-los de volta à delegacia de polícia, a fim de que as investigações prossigam requerendo ou não que novas diligências sejam realizadas e a solicitação de arquivamento ou o oferecimento de denúncia à Justiça ${ }^{113}$.

Devido ao grande volume de inquéritos que ficam sob a responsabilidade de cada promotor, geralmente os IPs que encontram-se relatados (conclusos) são, por eles, priorizados e os demais são postos de lado. Apenas em casos excepcionais, quando há repercussão na mídia ou relevância pessoal dos envolvidos, eles analisam o processo antes de ser relatado e elaboram "promoções", solicitando diligências à autoridade policial. Entretanto, é raro que os casos de "autos de resistência" estejam inclusos nesse rol, sendo frequente, como anteriormente assinalado, que os prazos sejam estendidos diversas vezes, gerando o chamado "pinguepongue" e, posteriormente, arquivados. Poucos são os promotores que dão a devida prioridade aos casos em questão ${ }^{114}$.

Logo, constata-se que o Ministério Público exerce um papel crucial na continuidade da política de extermínio perpetrada pelo Estado, pois caso os promotores atuassem de maneira mais incisiva, possivelmente, não teriam tantos Inquéritos Policiais de "homicídios provenientes de autos de resistência" sendo arquivados $\mathrm{e}$, portanto, não esclarecidos e não responsabilizados. Nessa perspectiva, Michel Misse, enfatiza:

\footnotetext{
112 Ibid, p. 84.

${ }^{113}$ Ibid, p. 85.

${ }^{114}$ Ibid, p. 85 .
} 
(...) a possibilidade de se contestar a versão de legítima defesa apresentada pelos policiais em casos de "auto de resistência" está em parte condicionada ao entendimento particular de alguns promotores de que estes sejam inquéritos em que eles devam atuar de maneira mais incisiva. Ainda que a má qualidade das investigações não ofereça elementos suficientes para apurar as circunstâncias das mortes, a presença de algum indício de ilegalidade pode induzir um promotor a levar o processo da incriminação adiante ${ }^{115}$.

Por fim, é necessário realizar algumas considerações acerca do relatório final do Inquérito Policial. Habitualmente redigido pelo delegado e, algumas vezes, por policiais civis, sendo revisado e assinado, posteriormente, pelo delegado. O relatório final diz respeito à conclusão da investigação, onde frequentemente argumenta-se ter ficado provada a legalidade da conduta policial nos casos de "autos de resistência", havendo, portanto, uma ou mais causas de exclusão de ilicitude previstas no art. 23 do CP. E, em alguns casos, há ainda, ao final, uma sugestão de arquivamento ou uma indicação que cabe ao MP avaliar o que deve ser realizado $^{116}$.

De acordo com o processualista penal Paulo Rangel, o IP tem como finalidade a apuração de infrações penais, ou seja, através dele procura-se indicar a autoria da infração, bem como comprovar a sua materialidade, a fim de dar ao Ministério Público elementos necessários que viabilizem a ação penal. Uma das características do Inquérito Policial, segundo Rangel, é ser unidirecional, segundo o qual não cabe à autoridade policial emitir qualquer juízo de valor quando da elaboração de seu relatório conclusivo. Nas palavras do doutrinador:

$\mathrm{O}$ inquérito policial tem um único escopo: apuração dos fatos objeto de investigação (cf. art. $4^{\circ}$, in fine, do $\mathrm{CPP}^{117}$ ). Não cabe à autoridade policial emitir nenhum juízo de valor na apuração dos fatos, como, por exemplo, que o indiciado agiu em legítima defesa ou movido por violenta emoção ao cometer o homicídio.

\footnotetext{
${ }^{115}$ Ibid, p. 86.

${ }_{117}^{116}$ Ibid, p. 87/88.

${ }^{117}$ Caput do art. $4^{\circ}$ do Código de Processo Penal: A polícia judiciária será exercida pelas autoridades policiais no território de suas respectivas circunscrições e terá por fim a apuração das infrações penais e da sua autoria.
} 
A autoridade policial não pode (e não deve) se imiscuir nas funções do Ministério Público, muito menos do juiz, pois sua função, no exercício das suas atribuições é meramente investigatória ${ }^{118}$.

Logo, tendo como base o preceituado pelo autor, a prática policial de emitir juízo de valor no relatório final, exteriorizando o seu convencimento e a partir disso sugerindo possíveis medidas a serem adotadas pelo MP, como verificado nos casos de "homicídios provenientes de auto de resistência", é contrário ao que dispõem o CPP e, é considerada um ranço do inquisitorialismo no seio policial.

\subsubsection{Arquivamento ou denúncia}

Consoante ao anteriormente explicitado, após o relatório final ser encaminhado à Central de Inquéritos, cabe ao promotor da PIP responsável pela delegacia denunciar os policiais por homicídio doloso, remeter os "autos" à Delegacia de Polícia para a realização de novas diligências, através de uma "promoção", ou solicitar ao juiz o arquivamento do inquérito, seja por entender inexistente o crime $^{119}$ (devido as possíveis excludentes de ilicitude presentes ou por qualquer outro motivo que o descaracterize como tal) ou por acreditar insuficiente o material probatório disponível.

Apesar de improvável, tendo em vista que não é comum a análise, pelos promotores, de inquéritos inconclusos, é possível que a denúncia seja redigida antes do relatório final ser encaminhado à PIP, desde que o IP contenha as peças fundamentais, como, por exemplo, o Auto de Exame Cadavérico (AEC) ${ }^{120}$.

Aliás, vale salientar, que muitos procedimentos são devolvidos à DP por carecerem de peças importantes, como os laudos técnicos, inclusive,

\footnotetext{
${ }^{118}$ RANGEL, Paulo. Direito Processual Penal. Rio de Janeiro: Lumen Juris, 2009, p. 90/91.

${ }^{119}$ De acordo com a doutrina penal, crime é o fato típico (encontra perfeita adequação na lei penal, portanto, trata-se de uma conduta proibida), ilícito (contrário ao direito) e culpável.

${ }^{120}$ MISSE, Michel; GRILLO, Carolina Christoph; TEIXEIRA, César Pinheiro; NERI, Natasha Elbas. Quando a polícia mata: homicídios por "autos de resistência" no Rio de Janeiro (20012011). Rio de Janeiro: NECVU; Booklink, 2013, p. 95.
} 
segundo promotores, o delegado jamais deveria redigir o relatório final sem que o AEC tenha sido confeccionado e juntado ao $\mathrm{IP}^{121}$.

Conforme anteriormente mencionado, observa-se, que os inquéritos de "autos de resistência", quase que em sua totalidade, resultam em um pedido de arquivamento por parte do MP, seja devido à precariedade das investigações realizadas pelas autoridades policiais, que resultam na carência de provas (laudos técnicos e testemunhas), ou em virtude da "fé pública" dos agentes, que é utilizada como prova central da legalidade de suas ações, resultando na prevalência da versão apresentada pelos policiais no RO, sendo indiferentes as demais evidências colhidas.

É necessário destacar, que mesmo havendo confissão do homicídio, como ocorre nos casos de "autos de resistência", não há prisão em flagrante, bem como os policiais envolvidos não são indiciados no inquérito, logo, não há elaboração do seu Auto de Qualificação, sendo incomum que seja solicitado que a FAC do policial seja anexada ao IP. A justificativa, segundo um promotor, é a de que "o policial precisa sair para trabalhar sem medo de acabar preso ${ }^{122,}$.

Além das dificuldades já explanadas, Misse cita em seu livro, que o porte de arma de fogo pela vítima do homicídio, bem como outros objetos que o caracterizariam como "criminoso", já são motivos suficientes para que seja solicitado o arquivamento do caso, pois são considerados indícios de que o policial teria agido em legítima defesa. No entanto, é necessário esclarecer que, muitas vezes, essas armas são "plantadas" pelos policiais, são as denominadas "velas"123, assim como os objetos. O que torna ainda mais inaceitável que esses arquivamentos ocorram.

Nesse sentido, há arquivamentos que são solicitados em razão das passagens que a vítima já teve pela polícia, ou seja, em função da sua Folha de Antecedentes Criminais (FAC), pois, segundo um promotor “(...) é muito

\footnotetext{
${ }^{121}$ Ibid, p. 96.

${ }^{122}$ Ibid, p. 96

${ }^{123}$ Ibid, p. 157.
} 
difícil condenar o cara que mata alguém com antecedentes criminais no júri $^{124 \%}$. Essa dificuldade foi citada por muitos promotores na pesquisa que Misse realizou, sendo assim, o MP apenas realiza denúncia nesses casos, se os antecedentes não forem graves e caso haja indícios muito fortes de que tenha sido uma execução.

Há casos em que o AEC evidência que não tratam-se de casos de "autos de resistência" e sim, de execuções. Seja porque ficam comprovados que os disparos foram efetuados a curta distância (queima-roupa), pelas costas ou em excesso, ou porque as vítimas apresentam indícios de tortura. Normalmente, as raras denúncias que são realizadas, fundamenta-se nos AECs, pouquíssimas são as que possuem outras provas, como testemunhas, por exemplo.

Cumpre salientar que, em muitos casos, devido, principalmente, à falta de testemunhas, bem como de projétil para a realização de confronto balístico, os promotores encontram dificuldades para individualizar a conduta dos policiais, o que contribuí para que não sejam realizadas muitas denúncias.

Nos casos em que há denúncia, o homicídio classificado como um "auto de resistência" passa a ser um homicídio doloso. Ou seja, a classificação administrativa da polícia que existia no IP deixa de existir na fase processual, não há, na nova fase, diferença entre os "homicídios provenientes de autos de resistência" e os demais ${ }^{125}$.

Em ambos os casos, solicitação de arquivamento ou denúncia, são encaminhados à Justiça, onde ganham um número de processo e são distribuídas para uma das quatro varas do Tribunal do Júri, por meio de sorteio. Competirá ao juiz sorteado aceitar ou não a denúncia, bem como concordar ou não com o arquivamento ${ }^{126}$.

\footnotetext{
${ }^{124} \mathrm{Ibid}$, p. 98.

${ }^{125}$ Ibid, p. 104.

${ }^{126}$ Código de Processo Penal - Art. 28: Se o órgão do Ministério Público, ao invés de apresentar a denúncia, requerer o arquivamento do inquérito policial ou de quaisquer peças de informação, o juiz, no caso de considerar improcedentes as razões invocadas, fará remessa do inquérito ou peças
} 


\subsubsection{Processo}

Frequentemente o desfecho dos casos classificados como "autos de resistência”, pela Polícia Civil, são as solicitações de arquivamento, como tem sido evidenciado ao longo desse capítulo. O pedido de arquivamento é realizado pelo promotor da PIP da Central de Inquéritos e é, geralmente, aceito pelos juízes, sendo o Inquérito Policial arquivado, oficialmente, como homicídio praticado em legítima defesa.

Com o arquivamento a narrativa policial ganha, enfim, o status de "verdade jurídica". Os policiais deixam de ser autores, enquanto a vítima do homicídio passa a ser eternamente vista como autora da resistência que levou o policial a matá-la ${ }^{127}$.

Nos raros casos em que os juízes rejeitam o pedido de arquivamento, com base no art. 28 do CPP, é em virtude dos Autos de Exame Cadavérico, quando estes indicam de modo contundente que houve execução ${ }^{128}$. Porém, vale dizer, que não são todos os juízes que têm esse cuidado de verificar com cautela as solicitações de arquivamento e observar os laudos técnicos de modo detalhado.

Nos casos excepcionais, em que há denúncia e esta é aceita, o crime tipificado é de homicídio, previsto no art. 121 do CP. A classificação "auto de resistência" não está presente nessa fase, visto que, é apenas, como outrora mencionado, uma classificação administrativa da polícia.

Parcela considerável das denúncias que são aceitas, fundamentam-se, assim como as rejeições de pedidos de arquivamento, nos AECs. Outras, devido à pressão realizada por movimentos sociais, por grupos ligados à

de informação ao procurador-geral, e este oferecerá a denúncia, designará outro órgão do Ministério Público para oferecê-la, ou insistirá no pedido de arquivamento, ao qual só então estará o juiz obrigado a atender.

${ }^{127}$ MISSE, Michel; GRILLO, Carolina Christoph; TEIXEIRA, César Pinheiro; NERI, Natasha Elbas. Quando a polícia mata: homicídios por "autos de resistência” no Rio de Janeiro (20012011). Rio de Janeiro: NECVU; Booklink, 2013, p. 107.

${ }^{128}$ Ibid, p. 108. 
defesa de direitos humanos, pela mídia ou por familiares da vítima ${ }^{129}$. Estas fundamentações também contribuem para futuras pronúncias dos casos ${ }^{130}$.

Após a denúncia ser acolhida, o processo é repassado ao promotor da vara, que pode reformular ou não a denúncia, sendo, posteriormente, o processo encaminhado para a análise daquele que efetuará a defesa do policial (advogado particular ou defensor público da vara). Na sequência, é marcada a Audiência de Instrução e Julgamento (AIJ), que está sujeita à disponibilidade da pauta da vara, sendo que esta prioriza os casos em que os réus encontram-se presos, logo, os casos originários de "autos de resistência", quase que em sua totalidade, são excluídos, visto que os policiais continuam soltos.

A nova regulamentação do Tribunal do Júri ${ }^{131}$ dispõe que a AIJ deve ser única, ou seja, que no mesmo dia devem ser ouvidas todas as testemunhas de acusação e defesa, seguido do depoimento dos réus, para então serem realizadas as alegações finais. Após concluídas todas essas etapas cabe ao juiz responsável pronunciar ou impronunciar os casos. Ocorre que em função da dificuldade de reunir todas as testemunhas em uma única data, esta fase acaba sendo fragmentada em duas ou mais, com o intervalo de tempo de alguns meses entre uma audiência e outra, mas a ordem em que as pessoas devem ser ouvidas segue sendo respeitada ${ }^{132}$.

Vale ressaltar, que após a AIJ ser marcada, é comum que ocorram uma série de adiamentos, o que contribuí para agravar a morosidade do processo penal.

\footnotetext{
${ }^{129}$ Ibid, p. 114.

${ }^{130}$ Ibid, p. 133.

${ }^{131}$ Lei 11.689, de 09 de junho de 2008. Altera dispositivos do Código de Processo Penal relativos ao Tribunal do Júri e dá outras providências.

${ }^{132}$ MISSE, Michel; GRILLO, Carolina Christoph; TEIXEIRA, César Pinheiro; NERI, Natasha Elbas. Quando a polícia mata: homicídios por "autos de resistência" no Rio de Janeiro (20012011). Rio de Janeiro: NECVU; Booklink, 2013, p. 115.
} 
Após o juiz anunciar a abertura da AIJ relatando o nome do réu e o tipo penal que lhe é imputado, realiza a leitura da denúncia e convoca a primeira testemunha da acusação para depor ${ }^{133}$.

Geralmente as testemunhas dos casos de "autos de resistências" são familiares e amigos da vítima que não presenciaram o crime, sendo, nesses casos, comum que as questões levantadas pelo promotor, advogado e juiz se centrem na figura do morto. Ou seja, as indagações feitas aos familiares e amigos são, somente, acerca da conduta moral da vítima. O promotor através das perguntas levantadas tenta obter informações de modo a caracterizar a vítima como um trabalhador, enquanto o advogado tenta caracterizá-lo como bandido.

Importa dizer que, em muitos casos, ocorrem determinados excessos por parte daquele que está inquirindo a testemunha, principalmente de advogados, que chegam a humilhar aquele que está prestando o depoimento ${ }^{134}$. Além disso, há, de certo modo, uma intimidação velada por parte dos policiais que estão sendo acusados de homicídio, visto que, estes estão presentes no momento que os testemunhos são colhidos, logo, é normal que as testemunhas sintam-se acuadas e sejam vagas em suas declarações, e muitas vezes afirmem que não estão acusando ninguém, por exemplo.

É bastante incomum que testemunhas que tenham presenciado o crime deponham. Isso é apontado por promotores do júri, como uma das grandes deficiências das investigações que reflete totalmente no trabalho por eles exercido, pois acaba por dificultar a acusação na fase processual, tendo em vista que não há testemunhos que possam ser usadas de modo a contrapor os depoimentos dos policiais ${ }^{135}$.

\footnotetext{
${ }^{133}$ Ibid, p. 116.

${ }^{134}$ Misse, em seu livro, relata um caso onde a testemunha é a mãe da vítima e, devido às perguntas e afirmações realizadas pelo advogado direcionadas a ela, sempre tentando desqualificar seu filho, bem como as informações que estão sendo prestadas, dando a entender que são mentiras ou que ela não conhece a rotina do filho, fazem com que ela fique nervosa e chore em muitas ocasiões. É possível, ao ler o relato, sentir na pele à humilhação por ela sofrida. Ibid, p. 118 a 125.

${ }^{135}$ Ibid, p. 117.
} 
Na fase de instrução o Ministério Público pode solicitar que sejam realizadas algumas diligências como, por exemplo, a reprodução simulada, que visa reconstituir o crime e, o confronto balístico, se porventura tenha sido arrecadado algum projétil no local do crime ou no corpo da vítima, a fim de que se saiba de que arma partiram os disparos. Ademais, os promotores podem solicitar que sejam juntadas as Folhas de Antecedentes Criminais dos policiais e as suas fichas disciplinares na PM, bem como, que sejam realizadas pesquisas junto ao Tribunal de Justiça para averiguar se estão respondendo a algum outro processo ${ }^{136}$.

Mas, no geral, promotores, defensores e juízes, concordam que as deficiências do inquérito - ausência de perícias no local do crime, precariedade das demais perícias, falta de testemunhas que presenciaram os fatos, por exemplo - tornam-se entraves no processo, dificultando o esclarecimento dos casos e a formulação de teses jurídicas por parte da acusação e, inclusive, da defesa ${ }^{137}$. Logo, em muitos casos, as diligências solicitadas na instrução não são suficientes para, sozinhas, fundamentarem a acusação.

A estratégia utilizada pela defesa, como citado anteriormente, é caracterizar a vítima como "bandido". Para isso, os advogados/defensores, indagam às testemunhas se a vítima tinha algum envolvimento com atividades ilícitas e, em caso de negativa, trabalham para desconstruir e desqualificar as informações prestadas.

Além disso, também questionam sobre a existência ou não de tráfico de drogas na comunidade em que houve a morte, e se a mesma ocorreu próximo a uma "boca de fumo". Pois confirmadas tais informações, elas são usadas para justificar confrontos entre policiais e traficantes no local. $\mathrm{Ou}$ seja, quando não estão tentando criminalizar a vítima, criminalizam a localidade, construindo a ideia de que a vítima estava em um local "reservado para bandidos e usuários de drogas".

\footnotetext{
${ }^{136}$ Ibid, p. 128.

${ }^{137}$ Ibid, p. 129.
} 
Nesse sentido, Misse concluí:

Inclusive se for demonstrado que havia boca ali e não se provar o envolvimento do morto com o tráfico, pode-se argumentar que os policiais cometeram homicídio culposo, não intencional, ou seja, que o morto foi atingido por uma bala da polícia durante uma troca de tiros com traficantes ${ }^{138}$.

Em determinados casos, são convocados para depor pela defesa, os comandantes de batalhão ou delegados, a fim de que certifiquem a periculosidade do tráfico de drogas no local do crime, bem como para informem sobre a existência ou não de uma operação policial autorizada na data do ocorrido ${ }^{139}$. Esses depoimentos, acrescidos de documentos escritos que formalizam a realização de operação no local, são os principais argumentos utilizados para legitimar a conduta policial, pois descaracterizam a ideia de que os policiais estariam realizando “justiçamentos” ilegais por conta própria ${ }^{140}$.

Há, ainda, casos em que a defesa solicita a ficha disciplinar dos policiais, com a finalidade de alegar de que tratam-se de homens íntegros.

Como outrora mencionado, os promotores encontram dificuldades na hora de individualizarem as condutas dos policiais envolvidos. Esta dificuldade favorece a defesa, pois aproveita-se disso para questionar a participação de cada policial (arrolado no processo) no homicídio da vítima.

Após todo esse processo, oitiva de testemunhas, produção de provas solicitadas pela defesa e pela acusação, as partes fazem suas alegações finais e a partir disso, o juiz decide pela pronúncia ou impronúncia do caso ou, ainda, pode julgar improcedente a pretensão do MP, nessa última hipótese, os réus são absolvidos sumariamente ${ }^{141}$.

Cumpre salientar, que tanto na pronúncia como na impronúncia não há julgamento de mérito da ação penal, o juiz somente decide acerca da

\footnotetext{
${ }^{138}$ Ibid, p. 130.

${ }^{139}$ Ibid, p. 132.

${ }^{140}$ Ibid, p. 133.

${ }^{141}$ Ibid, p. 134.
} 
existência de indícios suficientes para que o caso seja ou não levado a júri popular.

Em caso de pronúncia, parcela ínfima dos casos, os policiais, réus da ação penal, vão a júri popular. Este momento é definido pelos operadores do direito como aquele em que a "sociedade" julga os policiais.

O Tribunal do Júri é composto por um juiz togado e sete jurados ${ }^{142}$ cidadãos leigos, sem conhecimento do Direito e das leis - estes últimos, também chamados de conselho de sentença, irão julgar o caso, enquanto o primeiro, o juiz, se houver condenação, irá fixar a pena.

Conforme apontado por Misse, é comum que os jurados absolvam os policiais nos casos de "autos de resistência", principalmente se as vítimas tiveram tido, em algum momento da vida, envolvimento com atividades ilícitas. Segundo um defensor: "A própria sociedade entende a posição do policial e o vê como agente da lei. No júri, ele não vê o PM como alguém que extorque na favela. Ele vê a imagem do policial como alguém que defende a sociedade ${ }^{143,}$.

Em virtude da ausência de testemunhas, prova com maior peso nessa fase do processo, os promotores têm dificuldade em convencer os jurados do contrário, pois as provas técnicas não são suficientes para formar o convencimento deles de que os policiais cometeram o crime. Sendo assim, os promotores, em suas falas perante o júri, enfatizam as incongruências das versões apresentadas pelos policiais ou reforçam que as declarações deles são narrativas-padrão. Alguns ainda citam dados de relatórios internacionais acerca dos homicídios cometidos por PMs no Rio de Janeiro, salientando, inclusive, que o Rio é campeão de "autos de resistência", e que "a lei não permite matar, não permite execução ${ }^{144 »,} \operatorname{logo}$, que tais condutas policiais

\footnotetext{
${ }^{142}$ Código de Processo Penal - Art. 447: O Tribunal do Júri é composto por 1 (um) juiz togado, seu presidente e por 25 (vinte e cinco) jurados que serão sorteados dentre os alistados, 7 (sete) dos quais constituirão o Conselho de Sentença em cada sessão de julgamento.

${ }^{143}$ MISSE, Michel; GRILLO, Carolina Christoph; TEIXEIRA, César Pinheiro; NERI, Natasha Elbas. Quando a polícia mata: homicídios por "autos de resistência" no Rio de Janeiro (20012011). Rio de Janeiro: NECVU; Booklink, 2013, p. 146.

${ }^{144}$ Ibid, p. 147.
} 
são inaceitáveis e constituem crime. No entanto, na maioria dos casos, isso não tem demonstrado ser suficiente para que o júri condene os policiais.

Constata-se, portanto, que as deficiências iniciadas nas investigações obstruem todo o processo que vêm em seguida e, que constituem uma das principais causas para absolvição dos policiais. E, além disso, verifica-se que a sociedade mantém impunes diversos policiais, não por não compreenderem que eles praticaram um homicídio e, portanto um crime, mas por concordarem com o crime praticado, por defenderem o discurso "bandido bom, é bandido morto", como já citado no item 2.1.6., ou seja, a sociedade acredita que matar "bandido" é fazer o bem ${ }^{145}$.

Outrora fora mencionado que algumas operações policiais resultam em um "auto de resistência" e uma prisão, onde o preso é investigado e processado por tentativa de homicídio contra os policiais. Nessas situações, o caso é registrado, na delegacia, como um flagrante e, poderá estar atrelado a ele um "homicídio proveniente de auto de resistência". E, como visto anteriormente, é comum que o "auto de resistência" seja arquivado, enquanto a tentativa de homicídio praticada pelo preso vai adiante, com denúncia e pronúncia do mesmo.

Apesar de serem situações semelhantes, sendo o diferencial o autor do fato (um civil e outro policial) e a consequência (um tentativa e outro homicídio) ou como definiu Misse, “com réus e vítimas sentados em lados $\operatorname{opostos}^{146,}$, geralmente, o júri condena o civil pela tentativa de homicídio, enquanto absolve o policial pelo homicídio praticado.

Portanto, observa-se que há certa incongruência na ação de todos os atores do processo (delegado, promotor, juiz e jurados - sociedade), pois agem de maneira totalmente diferente conforme quem estiver na figura do réu.

\footnotetext{
${ }^{145}$ Ibid, p. 149.

${ }^{146}$ Ibid, p. 150.
} 
Ressalta-se que há casos em que o promotor pede desclassificação da tentativa de homicídio contra os policiais, por falta de provas de que o preso tenha atirado com a intenção de matar, nesse casos a vara do júri não tem competência para atuar, pois o crime passa a ser, simplesmente, de resistência, logo, a competência para julgar passa a ser da vara criminal comum $^{147}$.

\subsection{Projeto de Lei $4.471 / 2012$}

No ano de 2012 foi proposto na Câmara dos Deputados o Projeto de Lei 4.471 que visa modificar alguns dispositivos do Código de Processo Penal. O PL estipula regras mais rigorosas a serem seguidas nas investigações dos "homicídios provenientes de autos de resistência", bem como dos casos de lesões corporais decorrentes de intervenções policiais.

Cumpre salientar que apesar do Projeto de Lei encontrar-se pronto para ser colocado na pauta do plenário da Câmara a fim de que seja votado, de acordo com as informações contidas na sua ficha, isso tem sido postergado em virtude de interesses dos líderes da Casa. Sobre isso, é válido frisar que o atual parlamento brasileiro é o mais reacionário dos últimos anos, logo, é possível vislumbrar mais procrastinações na votação desse Projeto de Lei.

Caso seja votado e tenha seu texto integralmente aprovado o projeto modificará a redação dos artigos 161, 162, 164, 165, 169 e 292 do CPP.

Entre os pontos principais do texto estão: a obrigatoriedade da preservação da cena do crime e da realização de perícia e coleta de provas imediatas; o prazo de dez dias para a elaboração dos laudos técnicos e, assim que finalizados, além de serem encaminhadas cópias dos laudos aos órgãos do Estado, uma deve ser enviada a família da vítima e, por fim, a instauração de inquérito para apuração do caso, sem prejuízo de eventual

${ }^{147}$ Ibid, p. 150. 
prisão em flagrante do agente policial que tenha praticado a lesão corporal ou o homicídio.

Importa dizer que o PL foi criado a partir da comoção de diversos operadores do sistema de justiça, profissionais de segurança pública e da sociedade civil organizada, todos preocupados com a deficiência das atuais investigações realizadas nos casos envolvendo o emprego da força letal do estado, pois, conforme exposto na justificação do próprio Projeto de Lei:

(...) a partir da classificação de um caso como "auto de resistência" ou "resistência seguida de morte" diversos pressupostos fundamentais de uma investigação eficaz deixam de ser adotados. Conforme relatam os profissionais que atuam com esta temática, a análise empírica de inúmeros autos de inquéritos aponta que vários deles apresentam deficiências graves, como a falta de oitiva de todos os envolvidos na ação, a falha na busca por testemunhas desvinculadas de corporações policiais e a ausência de perícias básicas, como a análise da cena do crime $^{148}$.

Logo, constatou-se a necessidade de correta apuração desses casos, pois do contrário, o Brasil incorre na violação de direitos humanos, bem como de tratados internacionais dos quais é signatário, visto que permite que execuções sejam rotineiramente realizadas por agentes estatais, sem que estes sejam responsabilizados.

Em recente ato realizado na $\mathrm{OAB} / \mathrm{RJ}$ sobre o tema, o deputado Paulo Teixeira, um dos autores do PL, apresentou dados acerca da violência policial que foram utilizados na fundamentação do referido projeto, tendo destacado:

No Rio de Janeiro, especificamente, um estudo da ONG Justiça Global [Human Rights Watch] examinou 12.560 autos de resistência e chegou à conclusão de que em $65 \%$ deles as vítimas foram mortas com tiro nas costas ou na nuca, o que mostra que não houve

\footnotetext{
${ }^{148}$ Projeto de Lei 4.471/2012, p. 3.
} 
resistência. Os autos de resistência, então, na prática protegem homicídios cometidos por policiais em serviço ${ }^{149}$.

A iniciativa do Projeto de Lei deve ter sua importância reconhecida e, também, incentivada, pois apesar de não prever alguns pontos importantes como, por exemplo, a autonomia da perícia técnica ${ }^{150}-$ ou seja, sua separação da Polícia Civil, aspecto fundamental para que as perícias sejam realizadas com imparcialidade, independência e, que os peritos tenham reais condições de trabalho, com melhores estruturas, o que adviria com a separação, pois teriam uma receita própria - o PL traz à tona uma discussão importante que deve ser travada com a sociedade e, além disso, é o primeiro passo para que outras iniciativas sejam tomadas para que mudanças efetivas ocorram no cenário atual.

Aliás, cumpre ressaltar que no mesmo ano em que o Projeto de Lei foi proposto, alguns meses depois, o Conselho de Defesa dos Direitos da Pessoa Humana (CDDPH), agora Conselho Nacional dos Direitos Humanos $(\mathrm{CNDH})^{151}$, vinculado à Secretaria de Direitos Humanos da Presidência da República, aprovou a Resolução $n^{\circ}$ 08, que faz uma série de recomendações a respeito dos casos que envolvam pessoas mortas por agentes policiais.

Dentre o recomendado pela Resolução está: a abolição do emprego, nos registros de ocorrência policial e inquéritos policiais, de expressões genéricas como "autos de resistência", "resistência seguida de morte" e, assemelhadas; a rigorosa investigação na ocorrência de casos de "homicídios provenientes de intervenção policial"; o afastamento imediato dos serviços de policiamento ostensivo ou de missões externas, ordinárias ou especiais dos policiais envolvidos na ação policial que resultou no homicídio.

\footnotetext{
${ }^{149}<$ http://www.oabrj.org.br/noticia/90989-oabrj-realiza-ato-pela-investigacao--dos-autos-deresistencia>. Acesso em: 01.06.2015.

${ }^{150}$ Atualmente poucos estados da federação têm uma perícia autônoma, na maior parte deles ela continua sendo subordinada à Polícia Civil.

${ }^{151}$ Lei 12.986, de 2 de junho de 2014.
} 
Portanto, é possível visualizar que, mesmo a passos lentos, o debate acerca do tema tem sido travado, no entanto, é necessário que medidas mais contundentes sejam adotadas, pois a vida dos moradores das favelas e periferias depende disso. 


\title{
4. Casos reais, vítimas invisíveis
}

\author{
"Nestes cemitérios gerais \\ não há morte isolada \\ mas a morte por ondas \\ para certas classes convocadas" \\ (João Cabral de Melo Neto - Dois parlamentos)
}

A fim de ilustrar o que fora apresentado anteriormente, este capítulo trará alguns casos relativos aos "autos de resistência", bem como, outros de extermínios praticados pelo Estado. Alguns foram retirados do livro "Assassinatos em nome da lei", do desembargador Sérgio Verani ${ }^{152}$ e os demais, de notícias veiculadas em jornais.

Pretende-se demonstrar que a conduta que leva ao que hoje é denominado "autos de resistência", é uma prática que remonta ao Brasil colonial, ou seja, sua existência é anterior à previsão legal que adveio na época da ditadura militar, período negro da história brasileira. Certamente, havia outra roupagem, no entanto, sua essência era a mesma, o extermínio de classes e grupos sociais oprimidos, excluídos e invisíveis da sociedade.

Ademais, o objetivo é, também, suscitar o questionamento de porque essa prática persiste até os dias de hoje, sendo legitimada pelo Estado e pela sociedade.

\subsection{Reminiscências}

O primeiro caso apresentado por Verani remonta ao período escravocrata brasileiro, diz respeito ao preto Martinho, escravo do Rev. Padre Alexandre Cidreira, que foi denunciado em julho de $1882^{153}$. Em resumo realizado pelo autor:

O escravo desobedeceu ao senhor porque passava fome e frio. Recebeu um tiro. O senhor nada sofreu. O escravo foi preso em flagrante por tentativa de homicídio e resistência. Foi denunciado e

\footnotetext{
${ }^{152}$ Há casos interessantíssimos apresentados no livro do Verani, no entanto não é possível que todos sejam citados no presente trabalho.

${ }^{153}$ VERANI, Sérgio. Assassinatos em nome da lei - Uma prática ideológica do Direito Penal. Rio de Janeiro: Aldebarã, 1996, p.29.
} 
pronunciado. A denúncia sustenta a "necessidade de severa repressão de tais atentados" $" 154$.

A história do preto Martinho segue contemporânea, como bem pontua Verani. Nos dias de hoje essa prática persiste, quando o indivíduo não morre, o que caracterizaria um "homicídio proveniente de auto de resistência" segundo a classificação dos policiais, o sujeito torna-se réu do processo e é acusado por tentativa de homicídio contra os policiais. Ou seja, quando não é vítima de um homicídio, torna-se autor da tentativa de outro. A política repressiva segue dando as cartas e definindo as regras do jogo.

No caso do preto Martinho não houve repercussão, pois, como já citado no item 2.1.2 do presente, a Constituição de 1824 ao prever diversos direitos e garantias fundamentais, não incluía no rol dos sujeitos dos referidos direitos e garantias os negros e índios. Dado o não reconhecimento de sua condição humana, os escravos, negros, eram considerados matáveis conforme o "desejo" de seus donos. Nos dias de hoje, raros são os casos em que há repercussão. A maioria dos episódios não choca e não revolta a sociedade, pois a violência perpetrada pelo Estado é direcionada aos segmentos marginalizados da sociedade, aos invisíveis, que vivem na condição de homo sacer $^{155}$, logo, considerados, também, sujeitos matáveis.

Por que a prática de excluir determinadas classes e grupos perdura? O que leva a vida do preto Martinho e de todos os invisíveis que são mortos cotidianamente em favelas, periferias e em outros recantos do Brasil, valer menos do que a vida daqueles que pertencem às classes mais abastadas?

O segundo caso apresentado por Verani, trata-se do primeiro após a previsão legal dos "autos de resistência", através da Ordem de Serviço $803 / 69$, e deve ser citado em virtude do seu simbolismo, pois representa o marco inicial de uma nova postura em relação aos homicídios praticados

\footnotetext{
${ }^{154}$ Ibid, p. 31.

155 AGAMBEN, Giorgio. Homo Sacer: o poder soberano e a vida nua. Belo Horizonte: Editora UFMG, 2002.
} 
por policiais, onde não é mais necessário ocultar os corpos, bem como a autoria do policial que praticou o crime ${ }^{156}$.

O caso é apresentado sob o título "Mariel Araújo Moryscotte de Mattos, em defesa da sociedade (inquérito $\mathrm{n}^{\circ}$ 6.610, maço 637, I Tribunal do Júri)". Mariel, integrante do recém-criado Grupo de Combate à Delinquência em Geral, grupo formado em 1969 e que veio a ser conhecido como "Grupo dos Onze Homens de Ouro", deu ordem de prisão a Arlindo Rodrigues Coelho, que estava praticando um assaltado à mão armada na lagoa, como este último resistiu à voz de prisão e alvejou o policial, Mariel, revidou a "injusta agressão" atingindo Arlindo com quatro disparos de arma de fogo, resultando em sua morte, segundo o que consta no "auto de resistência" lavrado na $\mathrm{DP}^{157}$.

O inquérito foi prorrogado por cerca de 20 anos e, posteriormente arquivado. Neste lapso temporal nenhuma investigação foi realizada acerca do caso, mesmo após reiteradas "promoções" e repreensões realizadas por promotores. Inclusive, vale destacar duas delas, sendo a primeira de 27/07/1970 e a segunda de 15/10/1973:

A promoção de fls. 34v. usque 36 é de abril deste ano!

Após a mesma nada foi feito! Por quê?

Basta estar envolvido um policial para que cruzem-se os braços e entrem as apurações em 'forno lento'... sob o protesto do MP, da opinião pública e da imprensa!

Advirto o Dr. Delegado para o fato, devendo em 60 dias ser procedidas as diligências determinadas, sob as penas $d a l e l^{158}$.

o episódio narrado não foi um simples caso de resistência. Trata-se, isto sim, de um crime de homicídio, cometido por motivo torpe e com requintes de crueldade ${ }^{159}$.

É possível vislumbrar, no caso em tela, o mesmo abandono e descaso que ocorrem nos Inquéritos Policiais de "autos de resistência" atuais. Não

\footnotetext{
${ }^{156}$ VERANI, Sérgio. Assassinatos em nome da lei - Uma prática ideológica do Direito Penal. Rio de Janeiro: Aldebarã, 1996, p. 46.

${ }^{157}$ Ibid, p. $37 / 38$.

${ }^{158}$ Ibid, p. 39.

${ }^{159}$ Ibid, p. 42.
} 
há qualquer intenção de esclarecer o ocorrido, bem como responsabilizar o policial por sua conduta.

Além disso, cabe ressaltar a postura adotada pela imprensa à época do ocorrido, que, do mesmo modo, não sofreu grandes transformações se comparada à imprensa atual, continua transformando crimes reais contra a vida em espetáculos de entretenimento, menosprezando o valor de uma vida e a dor daqueles que perderam entes queridos na política de combate permanente adotada pelo Estado.

O extermínio não é apenas reconhecido publicamente, como enaltecido pela sociedade que o compreende como necessário: "A polícia deve trabalhar sempre assim. Não há porque esconder do público e da imprensa um combate dessa espécie, onde a lei predominou sobre o crime em defesa da sociedade ${ }^{160 ",}$, comentou o delegado Godofredo em entrevista concedida ao Jornal O Globo, intitulada "Lei X Crime".

Outro caso, também apresentado por Verani que possui caráter emblemático, refere-se à morte do rapaz Alexandre Carlos Alves dos Santos, pardo, de 22 anos, que ocorreu em 1982.

Procurado por suspeita de furto, ao ser encontrado o rapaz sacou uma pistola e efetuou alguns disparos, segundo o informado pelo detetive. Este, em seguida "desferiu um tiro, que o atingiu pelas costas". Em despacho no RO o delegado afirmou que a resistência estava caracterizada, logo a conduta policial foi correta, que "tinham a obrigação de evitar a fuga do perigoso indivíduo, que era um verdadeiro micróbio social"161. Posteriormente, o MP ao solicitar arquivamento do caso profere as mesmas palavras do delegado, chamando a vítima de "micróbio social"162.

Esse caso é emblemático por diversas razões: pelo disparo ter sido efetuado quando a vítima encontrava-se de costas; pela afirmação do delegado de que os agentes tinham a obrigação de evitar a fuga e, por fim,

\footnotetext{
${ }^{160}$ Ibid, p. 47.

${ }^{161}$ Ibid, p. 93.

${ }^{162}$ Ibid, p. 94
} 
por terem, tanto delegado como promotor, "qualificado" a vítima como "micróbio social".

Ora, o que está configurado é o excesso do uso da força por parte do delegado, evidenciando-se a prática do “justiçamento". Sob hipótese alguma está caracterizada, na ação policial, a legítima defesa, uma das causas de excludente de ilicitude ${ }^{163}$. Haja vista, que dentre as funções das autoridades policiais e de seus agentes não constam o dever de matar, bem como, de que devem evitar a fuga ${ }^{164}$, o que está previsto no art. 292 do CPP é o uso dos meios necessários para defender-se ou para vencer a resistência, contudo, obviamente, matar não se enquadra nos meios necessários. Ademais, vale ressaltar, que ao atirar pelas costas da vítima, o delegado não deu sequer condições de defesa a ela, bem como, tal circunstância descaracteriza a resistência alegada pela autoridade policial.

Por fim, a "qualificação", ou seria melhor dizer, a desqualificação realizada pelo delegado e ratificada pelo promotor, ao chamarem a vítima de "micróbio social", é mais uma violência praticada pelo Estado.

O tratamento empregado à vítima, cheio de simbolismo, reforça o que vem sido defendido ao longo desse capítulo: os seres oprimidos, excluídos e invisíveis da sociedade são seres matáveis vivendo, portanto, em um estado de exceção permanente, submetidos a políticas de controle social penal de caráter excludente, seletivo e classista que não teme ceifar suas vidas.

\footnotetext{
${ }^{163} \mathrm{O}$ artigo 23 do Código Penal, que prevê as causas de excludente de ilicitude, também prevê a sua não aplicabilidade nos casos em que o agente faz uso excessivo da força. Conforme o texto do parágrafo único: $\mathrm{O}$ agente, em qualquer das hipóteses deste artigo, responderá pelo excesso doloso ou culposo.

${ }^{164}$ Nesse sentido, há um julgado de 2003: "a lei proíbe à autoridade policial, aos seus agentes e a quem quer que seja desfechar tiros de revólver ou pistola contra pessoas em fuga, mais ainda contra quem, devida ou indevidamente, sequer havia sido preso efetivamente" (STJ, REsp 402.419/RO, $6^{\text {a }}$ T., Rel. Min. Hamilton Carvalhido, j. 21/10/2003).
} 


\subsection{Inimigos de uma guerra particular, a banalização da morte}

No início da década de 1990, o Brasil adotou a política de "tolerância zero", iniciava-se nesse período a guerra às drogas. A partir de então, busca-se construir no imaginário social a ideia do traficante como inimigo público a ser combatido ${ }^{165}$.

No que concerne ao estado do Rio de Janeiro, essa política deu ensejo ao recrudescimento das ações policiais, bem como a prática rotineira de ocupação das favelas por policiais militares e pelas Forças Armadas, a fim de realizarem o controle social das classes tidas como subalternas. A política de extermínio das classes e grupos sociais oprimidos, dos invisíveis também foi agravada.

Coincidem com essa época as primeiras chacinas que ocorreram no estado do Rio após a reabertura democrática, a começar pela chacina de Acari (1990), onde onze pessoas, dentre as quais três meninas e oito rapazes, foram levados à força por homens que se diziam policiais. Até hoje nenhum dos jovens ou seus corpos foram localizados. No ano de 2010, vinte anos após a chacina, o inquérito foi encerrado devido à prescrição do crime ${ }^{166}$, os responsáveis nunca foram punidos. Á época muitos órgãos, dentre eles a $\mathrm{OAB} / \mathrm{RJ}$ criticou o descaso das autoridades judiciárias na apuração do ocorrido $^{167}$.

Em 1993 ocorreram as chacinas da Candelária e a de Vigário Geral. $\mathrm{Na}$ chacina da Candelária oito jovens sem-teto, dentre eles seis menores, foram executados por $\mathrm{PMs}^{168}$, muitos enquanto dormiam e outros no momento em que fugiam dos disparos. Na chacina de Vigário Geral, vinte e

\footnotetext{
165 SOUZA, Taiguara Libano Soares. Constituição, Segurança Pública e Estado de Exceção Permanente: A Biopolítica dos Autos de Resistência. 2010. 217 p. Dissertação de Mestrado Departamento de Direitoda Pontifícia Universidade Católica do Rio de Janeiro, Rio de Janeiro, p. 113.

166 <http://www.anovademocracia.com.br/no-69-100111/3099-20-anos-da-chacina-de-acari> Acesso em: 29.05.2015.

$167<\mathrm{http} / /$ sao-paulo.estadao.com.br/noticias/geral,chacina-de-acari-faz-20-anos-sem-punicao-imp,586398>. Acesso em: 29.05.2015.

168 Dentre os PMs que foram julgados pela chacina, três foram absolvidos, os outros foram condenados e expulsos da corporação, mas vale dizer que dois deles, posteriormente, receberam indulto, tendo suas penas extintas.
} 
um moradores foram assassinados por um grupo de extermínio conhecido como "Cavalos Corredores", composto por policiais militares ${ }^{169}$. Este massacre levou o Brasil a julgamento na Organização dos Estados Americanos (OEA) por violações de direitos humanos.

No governo Marcello Alencar (1995-1998) houve mais duas chacinas, ambas em Nova Brasília, no Complexo do Alemão. Uma delas ficou conhecida como chacina da Nova Brasília ${ }^{170}$, o caso teve repercussão internacional e o inquérito passou a ser monitorado pela Comissão Interamericana de Direitos Humanos $(\mathrm{CIDH})^{171}$.

Também foi no governo de Marcello Alencar que foi implementado a "gratificação faroeste". Concedida aos policiais civis e militares e, aos bombeiros militares, que recebiam um estímulo monetário pelo índice de letalidade que empreendiam. Após a promulgação do decreto ${ }^{172}$ que previa a bonificação, o número de homicídios subiu exponencialmente e o instituto dos "autos de resistência" ganhou destaque, pois era utilizado com maior frequência para designar as mortes resultantes de ações policiais, em contrapartida o número da criminalidade não diminuiu, o que gerou uma série de polêmicas, resultando na sua revogação em 1998. Porém, a prática do policiamento baseado no extermínio permanece ${ }^{173}$.

Vale ressaltar que as gratificações, aliadas às promoções por bravura, fizeram com que os homicídios classificados como "autos de resistência" passassem de três pessoas por mês, no começo de 1995, para mais de vinte por mês, em $1996^{174}$.

\footnotetext{
${ }^{169}$ Dos 52 PMs acusados, apenas sete foram condenados.

${ }^{170}$ Quatro policiais civis e dois PMs foram denunciados pelo MP por envolvimento numa operação da favela Nova Brasília, que resultou na morte de treze pessoas.

$171<\mathrm{http} / / / \mathrm{www}$.estadao.com.br/noticias/geral,mp-do-rio-denuncia-seis-policiais-por-chacina-em1994,1033747>. Acesso em 29.05.2015.

${ }^{172}$ Decreto $^{\circ} 21.753$, de 08 de novembro de 1995.

${ }^{173}$ SOUZA, Taiguara Libano Soares. Constituição, Segurança Pública e Estado de Exceção Permanente: A Biopolítica dos Autos de Resistência. 2010. 217 p. Dissertação de Mestrado Departamento de Direitoda Pontifícia Universidade Católica do Rio de Janeiro, Rio de Janeiro, p. 126.

${ }^{174}$ MISSE, Michel; GRILLO, Carolina Christoph; TEIXEIRA, César Pinheiro; NERI, Natasha Elbas. Quando a polícia mata: homicídios por "autos de resistência" no Rio de Janeiro (20012011). Rio de Janeiro: NECVU; Booklink, 2013, p. 16.
} 
Verifica-se que a "gratificação faroeste", foi a legalização da pena de morte de maneira "clandestina" no estado do Rio de Janeiro, visto que a pena de morte é inconstitucional no Brasil, estimulando o uso do instituto dos "autos de resistência", para escamotear execuções, ou, como bem definiu Verani, os "assassinatos em nome da lei".

Aliás, vale salientar que o perfil das vítimas dessa prática são os jovens, negros, pardos, pobres, que moram em favelas ou em periferias, evidenciando a forte tendência à criminalização da pobreza no Rio de Janeiro. Mais uma vez, os invisíveis da sociedade, que vivem na condição de homo sacer, na mira da política extermínio da polícia carioca.

Ao longo dos anos, outras chacinas ocorreram no estado do Rio, dentre elas estão: a chacina do Borel (2003), do Caju (2004), da Baixada (2005), do Jacarezinho (2007), do Complexo do Alemão (2007), da Providência (2008), de Japeri (2012), da Maré (2013) e de Duque de Caxias $(2014)^{175}$.

Em 2007, no governo do Sérgio Cabral (2007-2010), os “autos de resistência" atingiram o seu ápice, sendo contabilizados 1330 casos do estado do Rio de Janeiro, e 902 na capital ${ }^{176}$. Os autos índices de letalidade devem-se a "nova" política de segurança implementada pelo governador, que introduziu uma nova tática militar de combate ao tráfico de drogas, através das chamadas "megaoperações"177, incursões policiais sistemáticas

\footnotetext{
${ }^{175}$ Cabe salientar que estas são algumas das chacinas que ocorreram no estado do Rio apenas a título de exemplo. Ademais, é possível que tenham ocorrido outras que não chegaram a ser noticiadas nas páginas dos jornais.

${ }^{176}$ MISSE, Michel; GRILLO, Carolina Christoph; TEIXEIRA, César Pinheiro; NERI, Natasha Elbas. Quando a polícia mata: homicídios por "autos de resistência" no Rio de Janeiro (20012011). Rio de Janeiro: NECVU; Booklink, 2013, p. 16.

${ }^{177}$ Aa título de exemplo seguem algumas notícias veiculadas:

- Extra - 27.06.2007 - Megaoperação no Alemão deixa 19 mortos. <http://extra.globo.com/noticias/rio/megaoperacao-no-alemao-deixa-19-mortos-681274.html>. Acesso em: 29.05.2015.

Site Terra - 16.02.2011 - Exército substituirá tropa que ocupa o Complexo do Alemão. $<$ http://noticias.terra.com.br/brasil/policia/exercito-substituira-tropa-que-ocupa-o-complexo-doalemao,b228cb5c75bda310VgnCLD200000bbcceb0aRCRD.html>. Acesso em: 29.05.2015.

- O Globo - 04.04.2014 - Pacificação: Forças Armadas ocupam o Complexo da Maré. <http://oglobo.globo.com/rio/pacificacao-forcas-armadas-ocupamcomplexo-da-mare-12101190>. Acesso em: 29.05.2015.
} 
nas favelas, com grande contingente de agentes da polícia civil, militar, e Força Nacional de Segurança ${ }^{178}$.

Estas operações foram progressivamente substituídas pelas ocupações estáveis e duradouras nas favelas, quando no final de 2008, foram implementadas, pela Secretaria de Segurança do Rio de Janeiro, as chamadas Unidades de Polícia Pacificadora (UPPs) ${ }^{179}$, que tem como proposta o policiamento comunitário de proximidade. No entanto, o projeto das UPPs não se estendeu a grande parte das favelas do Rio de Janeiro, logo, a política de confronto e de extermínio não foi superada.

Vale ressaltar, que há muitas críticas a serem feitas ao projeto das UPPs, tendo em vista que, espera-se que o Estado esteja presente, em todos os territórios (não somente no asfalto), não apenas com políticas de segurança pública, mas com iniciativas nas áreas de educação, cultura, saúde e saneamento básico, por exemplo, o que não ocorre na maior parte das favelas que foram pacificadas.

É necessário salientar ainda, que há uma série de denúncias em relação às UPPs, sobre abusos perpetrados pelos policiais, que violam direitos humanos e civis dos moradores das comunidades rotineiramente.

Em abril deste ano, durante uma operação no Complexo do Alemão, no Rio de Janeiro, quatro pessoas foram mortas em menos de $24 \mathrm{~h}$, dentre elas um menino de 10 anos, Eduardo de Jesus Ferreira, morto com um tiro de fuzil ${ }^{180}$ na porta de casa durante a ação da Polícia Militar. Em nota, a polícia admitiu a morte da criança, mas alegou que foi uma fatalidade em meio ao confronto entre policiais e traficantes. A mãe de Eduardo, em

\footnotetext{
${ }^{178}$ SOUZA, Taiguara Libano Soares. Constituição, Segurança Pública e Estado de Exceção Permanente: A Biopolítica dos Autos de Resistência. 2010. 217 p. Dissertação de Mestrado Departamento de Direitoda Pontifícia Universidade Católica do Rio de Janeiro, Rio de Janeiro, p. 129.

${ }^{179}$ Já foram implementadas, entre 2008 e 2014, 38 UPPs. <http://www.upprj.com/>. Acesso em: 30.05.2015.

${ }_{180}<$ http://g1.globo.com/rio-de-janeiro/noticia/2015/04/laudo-afirma-que-tiro-que-matou-eduardono-alemao-e-de-fuzil.html $>$. Acesso em: 30.05.2015.
} 
entrevista, informou ter sido ameaçada pelo mesmo policial que efetuou o disparo.

Eduardo foi mais uma vítima da guerra às drogas, assim como tantos outros que não chegam às páginas dos jornais, que são invisíveis para a sociedade e para o Estado. A polícia frequentemente alega estar em confronto, ter havido resistência por parte do opositor, logo, ter sido uma ação "legal" ou ter sido uma morte por bala perdida e, portanto, uma fatalidade. Porém, se a política de segurança não fosse repressiva, não fosse uma política de extermínio não seriam perdidas tantas vidas.

Esses episódios que chocam o Brasil revelam um histórico de violência letal da polícia no estado do Rio de Janeiro direcionada a um segmento específico, as camadas marginalizadas da população. E em função da impunidade, da não responsabilização dos agentes policiais que empreendem essas práticas de barbárie, há a perpetuação de violações de direitos humanos, bem como da política de extermínio. Nesse sentido, exprime a Corte Interamericana de Direitos Humanos (CIDH) em um de seus julgados:

em casos de execuções extralegais, é essencial que o Estado investigue eficazmente a depravação ao direito à vida e puna todos aqueles responsáveis, especialmente quando agentes do Estado estão envolvidos, uma vez que se não atuar dessa maneira criará um ambiente de impunidade e condições para que tais eventos tornem a ocorrer $^{181}$.

Portanto, é necessário que a atual deficiência na apuração das circunstâncias dos fatos, que impossibilita que sejam esclarecidos como deram-se as mortes, seja sanada. É imprescindível que o Estado investigue toda e qualquer morte praticada por agentes policiais. Desse modo, será possível pensar um país onde não haja execuções, um país em que um

\footnotetext{
${ }^{181}$ Corte Interamericana de Direitos Humanos (CIDH), caso Myrna Mack-Chang v. Guatemala, Sentença de 25 de novembro de 2003. In SOUZA, Taiguara Libano Soares. Constituição, Segurança Pública e Estado de Exceção Permanente: A Biopolítica dos Autos de Resistência. 2010. 217 p. Dissertação de Mestrado - Departamento de Direitoda Pontifícia Universidade Católica do Rio de Janeiro, Rio de Janeiro, p. 192.
} 
segmento específico da população não viva no estado de exceção, mas sim que tenha seus direitos e garantias respeitados plenamente. 


\section{Conclusão}

Após a trajetória percorrida ao longo desse trabalho, alguns questionamentos parecem ser fundamentais e necessários: A quem essa política de extermínio atende? Quais interesses e ganhos estão por trás de todas essas mortes? Porque, afinal, não falou-se em mortes aleatórias e sim de uma força letal do estado direcionada a um segmento específico da população, aos invisíveis, pobres, jovens, negros, que moram em favelas ou periferias, os excluídos sociais que são apenas, como Galeano brilhantemente coloca, números. Eles não têm nomes, não aparecem na história universal, mas sim nas páginas policiais (quando aparecem) e, suas vidas valem menos do que a bala que os mata.

Através do delineamento histórico da formação do Estado brasileiro realizado no princípio deste trabalho, verificou-se que em todos os momentos na história do Brasil existiram sujeitos excluídos e, portanto, descartáveis: índios, escravos, capoeiras, pobres, traficantes ou qualquer outro grupo que não tenham conseguido inserir na ordem econômica vigente. Todos, em algum momento, foram subjugados por aqueles que detinham o poder, tendo suas vidas condicionadas à mera vida nua, considerados seres matáveis. E, a partir desse contexto, foi possível constatar que o extermínio andou e anda lado a lado com o estado de exceção e, em alguns casos, ambos andaram e andam lado a lado com o Estado Democrático de Direito.

Acerca do estado de exceção, é válido pontuar, que sua aplicabilidade à realidade brasileira baseou-se nas categorias propostas por Vieira. Sendo assim, buscou-se apontar, nos diversos contextos políticojurídicos transcorridos ao longo dos séculos, a qual categoria cada um deles pertencia, inclusive, naqueles onde o estado de exceção não foi determinado de modo objetivo pelo direito, sendo apenas uma classificação descritiva, como é o caso, dos períodos tidos como democráticos. 
Nesse sentido, importa frisar, que o atual Estado Democrático brasileiro convive perfeitamente com o estado de exceção, sendo este último restrito a determinados territórios e camadas sociais.

Isso se deve, pois o Brasil, entre a transição da ditadura militar e da abertura democrática, estava entranhado do autoritarismo dos anos de chumbo e, após a promulgação da Constituição de 1988, resquícios desse autoritarismo continuaram presentes, refletindo diretamente nas políticas de segurança públicas adotadas pelo Estado brasileiro nos dias de hoje. Ademais, a presença quase imperceptível do Estado em determinados territórios e a cidadania de baixa intensidade que são destinadas as pessoas que lá vivem, contribuem para a existência e permanência do estado de exceção.

Nessa perspectiva, verificou-se que as políticas repressivas e estratégias violentas de controle social, resquícios dos regimes autoritários, visam assegurar a preservação do status quo dos detentores do poder e, para tanto, milhares de pessoas são mortas por ano nas favelas e periferias das grandes cidades. Ou seja, viabiliza-se a execução de diversos indivíduos de um segmento específico da população em prol do poder e da segurança de outro. E, como constatado ao longo do trabalho, os "autos de resistência" tem papel fundamental para que este cenário seja mantido.

Ao serem usados de maneira indiscriminada, os "autos de resistência" asseguram que os algozes daqueles que tiveram suas vidas ceifadas não sejam responsabilizados. E, o Estado, por meio dos demais atores do judiciário, ao não investigar e não elucidar os casos é cúmplice dessas mortes. Portanto, apesar das mortes serem atribuídas, especificamente, aos policiais que disparam as armas, todos os personagens que atuam posteriormente, ao serem coniventes com essas condutas policiais, também são, de certo modo, responsáveis.

Verificou-se que parcela considerável dos casos de "autos de resistência" não é investigada, sendo, posteriormente arquivada. Isso se 
deve, como pontuado ao longo do capítulo 3, em virtude da falta de interesse que policiais, delegados, promotores e alguns juízes expressam em relação a esses casos, pois menosprezam as vidas daqueles que foram mortos, por tratarem-se, em sua maioria, de "bandidos", estes considerados desprovidos de dignidade, de direitos e de humanidade.

Logo, constata-se que o discurso "bandido bom, é bandido morto" que predomina na sociedade, também está presente nas instituições policiais e nos órgãos do judiciário, resvalando nas práticas e omissões de grande parcela desses atores, como anteriormente mencionado.

Ao longo do trabalho corroborou-se que é imprescindível que o Estado investigue toda e qualquer morte praticada por agentes policiais. Pois, a partir do momento que medidas nesse sentido forem adotadas, será possível pensar em um Estado que não mate sua população e fique impune.

Nessa perspectiva, alguns debates já foram travados, como citado no item 3.2. Contudo, ainda são resoluções "tímidas", é necessário que as discussões acerca dos "autos de resistência" sejam ampliadas, que atinjam e envolvam todos os âmbitos da sociedade.

Ademais, é fundamental que o Estado estenda essa discussão e comece a pensar em outras providências para conter o uso desenfreado da sua força letal. Que pense nos benefícios em ter uma polícia desmilitarizada e uma política de segurança pública que contemple todos os cidadãos, que respeite-os integralmente, que não seja pensada pela ótica da exceção, aviltação e extermínio, mas como segurança cidadã.

Por fim, é imprescindível que o olhar diferenciado que o Estado emprega sob determinadas classes e grupos sociais seja modificado, é necessário que todos cidadãos sejam concebidos como sujeitos ativos das políticas públicas e não como objetos. Enfim, é essencial que todos os cidadãos brasileiros sejam contemplados pela cidadania, que todos tenham seus direitos e garantias, previstos na Constituição Federal, respeitados 
integralmente e, sob hipótese alguma tenham suas vidas reduzidas a condição de homo sacer.

Desse modo, será possível não apenas pensar, mas consolidar a democracia em todos os territórios - nas favelas e periferias. Bem como, fazer prevalecer a vida, a segurança de todos os cidadãos e a concretização dos direitos humanos em detrimento da atual política de segurança pública de extermínio, que está fadada ao fracasso, pois além de não reduzir a criminalidade, ceifa vidas e sonhos. 


\section{Referências Bibliográficas}

AGAMBEN, Giorgio. Estado de exceção. São Paulo: Boitempo, 2004. . Homo Sacer: o poder soberano e a vida nua. Belo Horizonte: Editora UFMG, 2002.

AUAD, Denise. Os direitos sociais na Constituição de Weimar como paradigma do modelo de proteção social da atual Constituição Federal Brasileira. In Revista da Faculdade de Direito da Universidade de São Paulo, jan/dez. 2008, v. 103, p. 337-355. Disponível em: <http://www.revistas.usp.br/rfdusp/article/viewFile/67809/70417>. Acesso em 11.05.2015.

BATISTA, Nilo. Punidos e mal pagos: violência, justiça, segurança pública e direitos humanos no Brasil de hoje. Rio de Janeiro: Revan, 1990. BATISTA, Vera Malaguti. Difíceis ganhos fáceis: drogas e juventude pobre no Rio de Janeiro. Rio de Janeiro: Revan, 2003.

BENJAMIIN, Walter. Magia e técnica, arte e política-Obras Escolhidas. Vol. 1. São Paulo: Brasiliense, 1987.

COSTA, Arthur Trindade Maranhão. Entre a lei e a ordem: violência e reforma nas polícias do Rio de Janeiro e Nova York. Rio de Janeiro: Editora FGV, 2004.

D'ARAÚJO, Maria Celina e CASTRO, Celso (orgs.). Ernesto Geisel. Rio de Janeiro, Editora FGV, 1997.

DORNELLES, João Ricardo W. Conflito e segurança- Entre pombos e falcões. Rio de Janeiro: Lumen Juris, 2003.

GALEANO, Eduardo. As veias abertas da América Latina. Rio de Janeiro: Paz e Terra, 1996.

O livro dos abraços. Porto Alegre: L\&PM, 2002.

FRAGOSO, Heleno Cláudio. A nova lei de segurança nacional. In Revista de Direito Penal de Criminologia, jan/jun. 1983, no 35 . Rio de Janeiro: Forense, p. 60-69. Disponível em: 
<http://www.planalto.gov.br/ccivil_03/revista/Rev_58/panteao/HelenoClau dioFragoso.pdf>. Acesso em 12.05.2015.

MENDES, Gilmar Ferreira; COELHO, Inocêncio Mártires; BRANCO, Paulo Gustavo Gonet. Curso de Direito Constitucional. São Paulo: Saraiva, 2010.

MISSE, Michel; GRILLO, Carolina Christoph; TEIXEIRA, César Pinheiro; NERI, Natasha Elbas. Quando a polícia mata: homicídios por "autos de resistência" no Rio de Janeiro (2001-2011). Rio de Janeiro: NECVU; Booklink, 2013.

NETO, João Cabral de Melo. Dois parlamentos. Madrid: Edição do autor, 1960.

NUCCI, Guilherme de Souza. Manual do Direito Penal, - Parte Geral e Especial. São Paulo: RT, 2006.

RANGEL, Paulo. Direito Processual Penal. Rio de Janeiro: Lumen Juris, 2009.

RIBEIRO, Darcy. O Brasil como problema. Rio de Janeiro: Francisco Alves, 1995. . O povo brasileiro: a formação e o sentido do Brasil. São Paulo: Companhia das Letras, 1995.

RINALDI, Alessandra de Andrade. Marginais, delinquentes e vítimas: um estudo sobre a representação da categoria favelado no tribunal do júri da cidade do Rio de Janeiro. In ZALUAR, Alba e ALVITO, Marcos (Orgs.). Um século de favela. Rio de Janeiro: Editora FGV, 2004.

SCHMITT, Carl. Teologia política. Belo Horizonte: Del Rey, 2006.

SOUZA, Taiguara Libano Soares. Constituição, Segurança Pública e Estado de Exceção Permanente: A Biopolítica dos Autos de Resistência. 2010. 217 p. Dissertação de Mestrado - Departamento de Direito da Pontifícia Universidade Católica do Rio de Janeiro, Rio de Janeiro.

VERANI, Sérgio. Assassinatos em nome da lei - Uma prática ideológica do Direito Penal. Rio de Janeiro: Aldebarã, 1996. 
VIEIRA, José Ribas. O autoritarismo e a Ordem Constitucional no Brasil. Rio de Janeiro: Renovar, 1988.

ZAVERUCHA, Jorge. Relações Civil-militares: o legado autoritário da Constituição brasileira de 1988. In TELLES, Edson e SAFATLE, Vladimir (Orgs). O que resta da ditadura: a exceção brasileira. Vol. 1. São Paulo: Boitempo, 2009.

\section{Sítios consultados}

http://www.abin.gov.br/

http://www.agenciabrasil.ebc.com.br/

http://www.anovademocracia.com.br/

http://www.brasilpost.com.br/

http://www.camara.leg.br/

http://www.cev-rio.org.br/

http://www.cnv.gov.br/

http://www.estadao.com.br/

http://www.extra.globo.com/

http://www.folha.uol.com.br/

http://www.isp.rj.gov.br/

http://www.oabrj.org.br

http://www.odia.ig.com.br/

http://www.oglobo.globo.com/

http://www.planalto.gov.br/

http://www.terra.com.br/

http://www.upprj.com/ 